Cornell University Law School Scholarship@Cornell Law: A Digital Repository

$12-2009$

\title{
U.S. Chamber of Commerce Liability Survey: Inaccurate, Unfair, and Bad for Business
}

Theodore Eisenberg

Cornell Law School, ted-eisenberg@lawschool.cornell.edu

Follow this and additional works at: http://scholarship.law.cornell.edu/facpub

Part of the Applied Statistics Commons, Corporation and Enterprise Law Commons, and the Courts Commons

\section{Recommended Citation}

Eisenberg, Theodore, "U.S. Chamber of Commerce Liability Survey: Inaccurate, Unfair, and Bad for Business" (2009). Cornell Law Faculty Publications. Paper 373.

http://scholarship.law.cornell.edu/facpub/373

This Article is brought to you for free and open access by the Faculty Scholarship at Scholarship@Cornell Law: A Digital Repository. It has been accepted for inclusion in Cornell Law Faculty Publications by an authorized administrator of Scholarship@Cornell Law: A Digital Repository. For more information, please contact jmp8@cornell.edu. 


\title{
U.S. Chamber of Commerce Liability Survey: Inaccurate, Unfair, and Bad for Business
}

\author{
Theodore Eisenberg*
}

\begin{abstract}
The U.S. Chamber of Commerce uses its Survey of State Liability to criticize judiciaries and seek legal change but no detailed evaluation of the survey's quality exists. This article presents evidence that the survey is substantively inaccurate and methodologically flawed. It incorrectly characterizes state law; respondents provide less than 10 percent correct answers for objectively verifiable responses. It is internally inconsistent; a state threatened with judicial hellhole status ranked first in the survey while venues not on the list ranked lower. The absence of correlation between survey rankings and observable activity suggests that other factors drive the rankings. Two factors may help explain them. First, persistent low ranking of Gulf Coast states indicates that corporate counsel cannot shed hostility to states that were prominent in asbestos and tobacco litigation, notwithstanding changes in state laws. Second, low rankings of populous states suggest respondents fail to distinguish between rates of events and the absolute number of events. Adverse events in large states may occur more often but not necessarily at higher rates than in small states. The Chamber's uses of the survey fail to account for the sample design, fail to account for the same respondent rating multiple states, fail to account for industry effects, and fail to distinguish among respondents based on their knowledge of a state. The survey may discourage investment in the United States. and corporate risk managers' views suggest that the survey promotes corporate behavior that needlessly endangers the public.
\end{abstract}

\section{INTRODUCTION}

Evaluating court performance is of perennial interest but methodologically challenging. As Choi, Gulati, and Posner note: "Everyone recognizes that there are better and worse courts and better and worse judges, but how does one evaluate courts and

\footnotetext{
*Henry Allen Mark Professor of Law and Adjunct Professor of Statistical Sciences, Myron Taylor Hall, Cornell University, Ithaca, NY 14853; email: ted-eisenberg@lawschool.cornell.edu.

My interest in evaluating the survey analyzed here arose after meeting with Louisiana's Ad Hoc Committee to Study Perceptions of the Legal System (the Committee), a 21-member group chaired by Louisiana Chief Justice Catherine D. Kimball. The Committee asked me to assess the Chamber's survey; in particular, the Committee wished to know whether the survey identified problems that Louisiana's legal system should address. The views expressed here are solely my own, I thank Kevin Clermont and Marhn Wells for comments. I have served as a legal consultant for plaintiffs' counsel in tobacco, asbestos, and pharmaceutical litigation.
} 
judges?" The U.S. Chamber of Commerce (the Chamber) Survey of State Liability ${ }^{2}$ (the survey), an annual survey that began in 2002, receives substantial attention. State governments use it to attract business, ${ }^{3}$ to criticize judiciaries and seek pro-business legal change, and to justify judicial salary increases. ${ }^{4}$ The Chamber and other business groups use the survey in court to support legal arguments to narrow actions against businesses. ${ }^{5}$ Delaware's Superior Court, presumably proud of Delaware's perennial number one survey rank, supplies links to the Chamber's surveys. ${ }^{6}$ But the Chamber's conclusions about West Virginia, a state it regularly criticizes, have been questioned ${ }^{7}$ and the Chamber's results are inconsistent with more objective methodology. ${ }^{8}$ To date, however, no detailed evaluation of the survey's quality or consistency with state law has been published. This article seeks to supply that evaluation.

Analysis suggests that the survey is methodologically flawed and provides little useful information for states assessing their liability systems or for businesses considering investment in states or in the United States. The survey lacks elementary social scientific objectivity and incorrectly characterizes state law. Objectively verifiable responses are correct less than 10 percent of the time. Respondents ignore legal rules and material events within states. States that allow punitive damages can be ranked higher with respect to punitive damages than a state that does not allow them at all. A state can be on a "judicial hellhole" watchlist but rank first in the Chamber's system while other venues not on the list rank lower.

Technical methodological flaws also abound. The Chamber's uses of the survey often fail to account for the survey sample design, fail to account for respondents rating multiple

\footnotetext{
${ }^{1}$ Stephen J. Choi, Mitu Gulati \& Eric A. Posner, Judicial Evaluations and Information Forcing: Ranking State High Courts and Their Judges, 58 Duke L.J. 1313, 1314 (2009).
}

\begin{abstract}
${ }^{2}$ For the 2008 survey results, see Inst. for Legal Reform [hereinafter "ILR"], Lawsuit Climate 2008, http:// www.instituteforlegalreform.com/index.php?option=com_ilr_harris_poll\&year=200, accessed 6/23/2009. References to the Chamber's annual survey are hereinafter of the form "[year] Survey."
\end{abstract}

${ }^{3}$ Choi et al., supra note 1 , at 1316, 1327.

${ }^{4}$ Id. at 1327. The American Legislative Exchange Council relies on the Chamber's rankings in evaluating states. The American Legislative Exchange Council, Arthur B. Laffer, Stephen Moore \& Jonathan Williams, Rich States, Poor States: ALEC-Laffer State Economic Competitiveness Index 143 (2d ed. 2009).

${ }^{5}$ E.g., Brief of Chamber of Commerce of the United States, 2004 WL 2125702, Henry v. Dow Chem. Co., 701 N.W.2d 684 (Mich. 2005); Amicus Curiae Brief of Wisc. Mfrs. \& Commerce, 2002 WL 32699975; Wischer v. Mitsubishi Heavy Indus. Am, Inc., 673 N.W.2d 303 (Wis. App. 2002).

${ }^{6}$ Dela. St. Cts., News Arch., http://courts.delaware.gov/Courts/Superior\%20Court/?news_prev.htm, accessed 6/23/ 2009 (though some links are broken).

${ }^{7}$ Choi et al., supra note 1, at 1345-47 (tbl. 8 showing West Virginia ranked more highly); Elizabeth G. Thornburg, Judicial Hellholes, Lawsuit Climates and Bad Social Science: Lessons from West Virginia, 110 W. Va. L. Rev. 1097 (2008).

${ }^{8}$ Choi et al., supra note 1 , at 1354 . 
states, fail to account for industry effects, and fail to report results separately for those with the self-reported greater knowledge of a state's legal system. Normally such a flawed study would not be worth evaluating. But the Chamber uses its large budget to promote the survey and, as noted above, the survey receives substantial attention.

The most damaging effects of the Chamber's survey likely are not on the states the Chamber attacks but on our whole country's fiscal and physical well-being. U.S. businesses invest largely based on criteria more relevant to their decisions than the Chamber's claims about state legal systems. ${ }^{9}$ But the Chamber's use of its survey to attack courts and juries creates false impressions about states and the United States that may discourage foreign investment. Since companies cannot control the states in which they may be sued and foreign companies are more likely to lack the "on-the-ground" accurate information that domestic companies have, they may unnecessarily fear doing business, or increasing investment, in the entire country. Evidence from large corporations' risk managers and neutral third parties, in contrast to the survey, suggests that the survey may encourage corporate actions that unnecessarily endanger the public.

This article describes the Chamber's methodology in Section II and describes the survey's fundamental bias in Section III, a bias exacerbated by a likely excess response rate from corporate counsel whose companies have lost cases. Section IV addresses demonstrable errors in the Chamber's treatment of state law, with treatment of punitive damages and class actions being especially problematical. Section V suggests that the respondents' hostility to Gulf Coast and large states stems from flawed information processing. Section VI identifies statistical methodological flaws in the survey. Section VII concludes.

\section{The Chamber's Methodology}

The Chamber's methodology varies over time but the basic approach has not changed. Rather than paraphrase and risk misdescription, I present the methodology largely by quoting with minor editing from the Chamber's most recent report of it. Sections II.A and II.B thus rely on the Chamber's description of the 2008 survey methodology.

\footnotetext{
${ }^{9}$ E.g., Public Citizen, New U.S. Chamber of Commerce Poll Ranking States' Liability Systems Is Part of a Disinformation Campaign to Restrict Consumer Rights (Mar. 8, 2005):

It becomes still clearer just how meaningless the Chamber's state ranking is when one compares it with other state business rankings. Some states that chronically languish at the bottom of the Chamber poll are cited by other sources as great places to do business. These include Texas, Illinois, Alabama, South Carolina and Florida-all named among the most desirable business climates in Site Selection magazine's 2004 ranking, which surveys corporate executives. Illinois, which placed 46th in the Chamber's 2005 ranking of state liability systems, was rated the third best business location in the country in the 2004 Site Selection survey. Alabama, South Carolina and Florida, all in the bottom 25 percent in the Chamber poll, made the 2005 Poll in a Corporate Top 10 Pro-Business States list.
}

See also http://www.justice.org/PressRoom/PressReleases/truth_about_chamber.pdf, at 4, accessed 6/25/2009 (survey of National Association of Manufacturers ranked lawsuit abuse as a minor concern); note 129, infra (drug company relocated from highly ranked Virginia to lower ranked New Jersey notwithstanding Chamber's claim to have detected a hostile legal environment in New Jersey for drug companies). 


\section{A. Sample Design}

A representative sample of companies with annual revenues of at least $\$ 100$ million annually was drawn using idExec, ${ }^{10}$ Dun \& Bradstreet, Access Markets International (AMI) Partners, Inc., and Aggressive List Management. An alert letter was sent to the general counsel at each company. ${ }^{11}$ This letter provided general information about the study, notified them that an interviewer from Harris Interactive would be contacting them, and requested their participation. It also included a fact sheet about the study, the 2007 press release, and an article about the 2007 results that was published by Bloomberg LLP. In addition to receiving an alert letter, some contacts were told that a $\$ 50$ or $\$ 100$ donation would be made to a charity in exchange for agreement to participate in the study. This initiative was implemented toward the end of the interview period in order to increase cooperation and assure an adequate sample.

The sample was segmented into two main groups. Of the 957 respondents, 57 were from insurance companies, with the remaining 900 interviews being conducted among public and private corporations from other industries. The proportion of interviews with insurance companies represents 6 percent of the total sample, which is the typical representation of insurance companies in the universe of companies with $\$ 100$ million or more in revenues. Since property casualty insurance companies have extensive experience with state liability systems, for the purposes of this study the Chamber worked to ensure that the proportion of insurance companies matched the overall population. ${ }^{12}$

\section{B. Telephone Interviewing Procedures}

The study utilized Harris Interactive's computer-assisted telephone interviewing system, whereby trained interviewers call and immediately input responses into the computer. This system reduces clerical error by eliminating the need for keypunching, since interviewers enter respondent answers directly into a computer terminal during the interview itself. This data entry program does not permit interviewers to inadvertently skip questions, since each question must be answered before the computer moves on to the next question. The data entry program also ensures that all skip patterns are correctly followed. The on-line data editing system refuses to accept punches that are out of range, it demands confirmation of responses that exceed expected ranges, and asks for explanations for inconsistencies between certain key responses.

To achieve high respondent participation, in addition to the alert letters, numerous telephone callbacks were made in order to reach the respondent and conduct the interview at a convenient time for the respondent.

${ }^{10}$ idExec, http://www.idexec.com/, accessed 7/1/2009.

${ }^{11}$ If the general counsel at a company could not be identified, the alert letter was sent to another senior person at the company such as the chief executive officer or senior vice president.

${ }^{12}$ The 2008 Survey also reports that: "Respondents had an average of 19.3 years of relevant legal experience (including their current position), had been with their company an average of 11.6 years, and had been in their current position an average of 9.1 years.” 2008 Survey at 28. 
Once a qualified respondent was identified, the respondent was first asked about his/her familiarity with several states. First, 24 states out of the list of 50 possible states were presented to the respondent. Within these 24 states, the 17 states presented were: Alaska, Hawaii, Idaho, Iowa, Kansas, Maine, Montana, Nebraska, New Hampshire, North Dakota, Rhode Island, South Dakota, Utah, Vermont, West Virginia, Washington, and Wyoming. These states were prioritized to get a sufficient number of evaluations, since in past study years, data for these states were based on fewer evaluations. The remaining seven states were randomly selected from the remaining states not mentioned above. Respondents were then given the opportunity to name any other state, aside from the states already presented, and specify if they were very or somewhat familiar with that state.

Respondents who were very or somewhat familiar with a state were given the opportunity to evaluate that state's liability system. Similar to 2007, the maximum number of states a respondent could evaluate was 10 . On average, each respondent evaluated four states, up from an average of three states in 2007. In previous years (2002-2006), respondents were given an opportunity to evaluate a maximum of 15 states, evaluating an average of six states. This was changed in 2007 to reduce the burden on respondents and increase the likelihood that they were familiar with the states they were rating.

\section{The Elements in the Survey}

The initial 2002 survey asked about 10 elements, with an overall state grade computed from them. The survey graded the elements on an "A" through "F" scale. In initially translating to numerical values, the Chamber assigned 4 to an A, 3 to a B, 2 to a C, 1 to a D, and 0 to an F. In 2006, the Chamber changed the number associated with each grade, raising the highest number to 5 for an $\mathrm{A}$ and the lowest number to 1 for an $\mathrm{F}^{13}$ To illustrate the responses for one state, Table 1 lists Delaware's results for the elements in 2002 and 2008 (the earliest and most recent results available as of this writing), the mean score for each element, and Delaware's state rank for each element. In 2006 the Chamber added an element about having and enforcing venue rules, and changed the class action element to include "mass consolidation suits" in addition to class action litigation. ${ }^{14}$

On the original scale, Delaware's overall state score, shown in the table's last row, was 3.2 in 2002; on the new scale Delaware's overall score in 2008 was 3.9. Due to the change in the numbers assigned to grades, the numerical difference means little and Delaware overall ranked first in both years. The reliability of the survey's relative rankings of states is discussed below.

\footnotetext{
${ }^{13} 2006$ Survey at 7 .
}

${ }^{14}$ Id. at 6. 
Table 1: Delaware Ratings on Key Elements of State Liability Systems $n$ for $2002=75 ; n$ for $2008=95$

\begin{tabular}{|c|c|c|c|c|}
\hline \multirow[b]{2}{*}{ Element } & \multicolumn{2}{|c|}{ Mean Grade } & \multicolumn{2}{|c|}{$\begin{array}{l}\text { Interstate Ranking } \\
\text { for the Element }\end{array}$} \\
\hline & 2002 & 2008 & 2002 & 2008 \\
\hline $\begin{array}{l}\text { Having and enforcing meaningful venue } \\
\text { requirements (added in 2006) }\end{array}$ & na & 4.1 & na & 1 \\
\hline $\begin{array}{l}\text { Overall treatment of tort and contract } \\
\text { litigation }\end{array}$ & 3.1 & 4.0 & 1 & 1 \\
\hline $\begin{array}{l}\text { Treatment of class action suits (mass } \\
\text { consolidation suits added in 2006) }\end{array}$ & 3.4 & 4.0 & 1 & 1 \\
\hline Punitive damages & 3.1 & 3.8 & 1 & 1 \\
\hline Timeliness of summary judgment/dismissal & 3.0 & 3.8 & 1 & 1 \\
\hline Discovery & 3.2 & 3.9 & 1 & 1 \\
\hline Scientific and technical evidence & 3.1 & 3.9 & 1 & 2 \\
\hline Noneconomic damages (added in 2006) & na & 3.8 & na & 3 \\
\hline Judges' impartiality & 3.4 & 4.2 & 1 & 1 \\
\hline Judges' competence & 3.5 & 4.3 & 1 & 1 \\
\hline Juries' predictability & 2.7 & 3.5 & 1 & 13 \\
\hline Juries' fairness & 2.9 & 3.7 & 1 & 10 \\
\hline Overall state grade & 3.2 & 3.9 & 1 & 1 \\
\hline
\end{tabular}

Nоте: "na" indicates that states were not ranked on the element in 2002. Different scales were used to assign numerical scores to letter grades in 2002 and 2008.

Sources: Chamber Surveys 2002, 2008.

\section{The Chamber's Methodology Assures a Biased SuRveY}

The Chamber's survey violates the elementary principle that evaluation of legal system performance should be based on input from both sides to disputes. Even if the Chamber limited its focus to corporate respondents, more balanced views were available from within corporations and those who study them. The bias introduced by the Chamber's decision to limit its sample to a narrow group of corporate lawyers is exacerbated by its decision to inform potential respondents of prior survey results.

\section{A. The Chamber's Biased Sample}

Observers objectively evaluating the fairness of legal systems act based on the obvious insight that asking only one side to a dispute about a system will yield biased results. It would not even occur to the 21 states that formally evaluate judges ${ }^{15}$ to seek input from only one side to a dispute. Credible evaluations ask for the opinions of both sides to disputes. For

\footnotetext{
${ }^{15}$ Institute for the Advancement of the American Legal System, Shared Expectations: Judicial Accountability in Context 8 (2006). Recommended best practices would also ask for evaluations from at least litigants and jurors as well as lawyers. Id. at 69.
} 
example, the Alaska Judicial Council is directed by law to evaluate the performance of judges to appear on retention election ballots. When the Council asks counsel about a judge's fairness it asks all of the attorneys in a case. ${ }^{16}$ Nevada recently reviewed all states' judicial evaluation procedures and designed a pilot study for the state's use. In surveying attorneys in the pilot project, Nevada used all attorneys listed in a case, not just those representing one side. ${ }^{17}$ When Delaware, the Chamber's favorite state, sought information about its own courts' fairness to respond to the Chamber's suggestion that Delaware was on the verge of becoming an infamous judicial hellhole, Delaware asked lawyers on both sides of the issue. ${ }^{18}$ By asking only corporate counsel, the Chamber's study is a caricature of what a serious evaluation of a liability system should look like.

The bias in the Chamber's sample likely exceeds the obvious bias of asking only one side and precludes the survey even from accurately assessing that one side's view of court performance. The vast majority of civil lawsuits settle or are dismissed before trial. ${ }^{19} \mathrm{~A}$ corporate decision to press to trial a potentially large case likely involves senior corporate counsel. When senior counsel approves a refusal to settle, he or she is going out on a limb. A loss at trial can be a personal professional setback. Being human, counsel probably is unconvinced by the adverse decision about what should have been the case's proper outcome. It is only natural to blame bias by the courts or juries in the forum of the loss.

After the loss, along comes the Chamber's annual survey, which, as indicated by Section II.A above, has had such a problem obtaining sufficient responses that the Chamber now pays respondents to reply. Is the hypothetical losing counsel more or less likely than the average survey target to respond to the survey? The professional setback is likely one of the most salient things about the legal system to this person, and the survey offers an opportunity to disapprove of the locale that caused the professional embarrassment. The embarrassment is exacerbated if the company not only lost at trial but suffered an award of punitive damages. Now counsel really looks bad. And company funds may be at risk because not all punitive damages awards can be covered by insurance. ${ }^{20}$

\footnotetext{
${ }^{16}$ Alaska Judicial Council, http://www.ajc.state.ak.us/retention/retent.htm, accessed 6/21/2009.
}

${ }^{17}$ Rebecca M. Thomas, James T. Richardson \& Matthew Leone, Nevada Judicial Evaluation Pilot Project, Final Report 19 (Grant Sawyer Center for Justice Studies 4/28/2009).

\footnotetext{
${ }^{18}$ Richard D. Kirk, Bartholomew J. Dalton, Edward M. McNally, Allen M. Terrell, Jr. \& Jeffrey M. Weiner, Special Committee on Superior Court Toxic Tort Litigation: Report and Recommendations (May 9, 2008), http:// courts.delaware.gov/Courts/Superior\%20Court/pdf/?asbestos_toxic_tort_report.pdf, accessed 6/23/2009.

${ }^{19}$ E.g., Theodore Eisenberg \& Charlotte Lanvers, What Is the Settlement Rate and Why Should We Care? 6 J. Empirical Legal Stud. 111 (2009).

${ }^{20}$ E.g., American Int'l. Specialty Lines Ins. Co. v. Res-Care Inc., 529 F.3d 649, 663 (5th Cir. 2008) (applying Texas law); Fairfield Ins. Co. v. Stephens Martin Paving, LP, 246 S.W.3d 653 (Tex. 2008). In the abstract, if litigation losses were unidormly distributed across states, a "losing counsel" response bias might apply across all states with no net effect on states' rankings. But majoy litigation losses (or wins for that matter) likely are not so distributed, as suggested by large movements in some states' year-to-year rankings. See Section V.A.
} 
The methodological point is not whether corporate counsel or the venue of the loss was correct. The point is that this counsel is more likely than the average corporate counsel to respond to the survey. So the Chamber not only limits survey responses to corporate counsel, thereby assuring only one side of issues is represented, it likely gets a disproportionate response rate from counsel who have overseen recently lost cases. A well-designed survey should seek to account for likely biases. ${ }^{21}$ The Chamber's does not.

\section{B. The Chamber Could Achieve Better Balance from Corporate Respondents}

Even if the Chamber wished to limit respondents to those within the business community, greater balance and a more reliable ranking of states could be achieved. One step would be to ask respondents within the company who are less likely to have been professionally embarrassed by an important litigation recommendation. Within large corporations, evaluation of the civil justice system varies by position within the company. Studies over time and across industries suggest that the Chamber's survey's claims of perceived excess corporate liability are not representative of corporate views.

The Weber Report, commissioned by the business group the Conference Board, was a survey of "the risk managers of 232 major U.S. corporations. . . . each having a minimum annual sales revenue of $\$ 100$ million." 22 It concluded that product liability concerns, even in 1986 at the height of concerns about insurance coverage and costs, had been exaggerated.

For the major corporations surveyed, the pressures of product liability have hardly affected larger economic issues, such as revenues, market share, or employee retention. Liability lawsuits, which are indeed numerous, are overwhelmingly settled out of court, and usually for sums that are considered modest by corporate standards.... Where product liability has had a notable impact-where it has most significantly affected management decision making — has been in the quality of the products themselves. Managers say products have become safer, manufacturing procedures have been improved, and labels and use instructions have become more explicit. ${ }^{23}$

The Weber Report's risk manager findings were largely replicated in a later study. Professor Gary Schwartz of UCLA Law School interviewed risk managers for California public agencies and the UCLA Medical Center. He asked whether potential liability caused their safety efforts, or whether efforts to improve safety were simply a desire to do the right thing. He found that all risk managers "emphasized that their efforts were due to the combination of both. A risk manager starts with the idea that accident avoidance is a good for its own sake. But the prospect of tort liability provides an important reinforcement as

\footnotetext{
${ }^{21}$ E.g., Steven Garber, Michael D. Greenberg, Hilary Rhodes, Xiaohui Zhuo \& John L. Adams, Do Non-Economic Damages Caps and Attorney Fee Limits Reduce Access to Justice for Victims of Medical Negligence?, $6 \mathrm{~J}$. Empirical Legal Stud. (forthcoming 2009).
}

${ }^{22}$ Nathan Weber, Product Liability: The Corporate Response (Conf. Bd. Report No. 893, 1987)

${ }^{23}$ Id. at 2. 
well as an essential way to sell the risk manager's proposals to others in the organization." ${ }^{24}$ Evidence from industry-specific studies is consistent with the risk managers' views. ${ }^{25}$

In conclusions relevant to the Chamber's interests, the Weber Report suggests that the Chamber's survey results would be quite different if the survey were more balanced. "The findings of the present survey also refute the general contention of a severe and deepening crisis in tort liability and insurance availability, at least for the nation's large corporations. The impact on the general economy, likewise, is believed to have been minor." 26

\section{Providing Respondents with Prior Years' Results}

One aspect of the Chamber's methodology increases the likelihood that the bias in a prior year's survey will continue in subsequent years. The Chamber states that it provided the 2008 respondents with "a fact sheet about the study, the 2007 press release and an article about the 2007 results that was published by Bloomberg LLP." So before a respondent is called, he or she knows the prior year's results. The Chamber's decision in the 2008 survey to pay respondents suggests that the number of responses for many states in earlier years was a concern. Providing respondents with an earlier year's results is itself troubling and providing earlier results that were based on too few responses is even more problematical. This may help explain why respondents continue to show little or no reaction to material changes in legal environments. ${ }^{27}$

\section{Assessing the Survey's Accuracy}

Biased samples promote invalid results but assessing accuracy can be challenging. For most survey elements it is not feasible to objectively assess the survey's accuracy. Responses to elements, listed in Table 1, relating to judge and jury fairness, treatment of scientific evidence, discovery, and timeliness of dismissals are not readily amenable to verification since they call for subjective opinions. One cannot objectively determine if respondents graded correctly for most elements since usually no grade is objectively correct or incorrect.

\footnotetext{
${ }^{24}$ Gary Schwartz, Reality in the Economic Analysis of Tort Law: Does Tort Law Really Deter? 42 UCLA L. Rev. 377, 415-16 (1994). Schwartz reported that one risk manager started his job with considerable skepticism over whether the tort system effectively deterred, but his job experiences led him to believe that "tort liability exerts a significant influence." Id. at 416.

${ }^{25}$ John D. Graham, Product Liability and Motor Vehicle Safety, in Peter W. Huber \& Robert E. Litan, eds., The Liability Maze: The Impact of Liability Law on Safety and Innovation 119, 181 (Brookings Inst. 1991) (evaluating motor vehicle industry); Nicholas A. Ashford \& Robert F. Stone, Liability, Innovation, and Safety in the Chemical Industry, in Huber \& Litan, supra, at 368 (evaluating chemical industry); Rollin B. Johnson, The Impact of Liability on Innovation in the Chemical Industry, in Huber \& Litan, supra, at 450, 452 (evaluating chemical industry); Judith P. Swazey, Prescription Drug Safety and Product Liability, in Huber \& Litan, supra, at 291 (pharmaceutical industry).

${ }^{26}$ Weber, supra note 22 , at 2 .

${ }^{27}$ Text accompanying notes 91-95, infra.
} 
Table 2: Most Important Issues for State Policymakers Who Care About Economic

Development to Focus on to Improve Litigation

Environment

\begin{tabular}{lr} 
A. 2002 Survey & \\
Tort reform issue & $18 \%$ \\
Punitive damages & $17 \%$ \\
Judicial competence & $6 \%$ \\
Selection of judges & $6 \%$ \\
[Other issues with lower percentages] & not shown \\
\hline B. 2008 Survey & $12 \%$ \\
Speeding up the trial process & $10 \%$ \\
Reform of punitive damages & $9 \%$ \\
Eliminate unnecessary lawsuits & $8 \%$ \\
Tort reform issues in general & not shown \\
[Other issues with lower percentages] &
\end{tabular}

Sources: Chamber 2002, 2008 Surveys, Table 4.

The survey's treatment of two questions, however, can be partially assessed by comparing them to state law. The survey's treatment of punitive damages and class actions reveals inaccurate legal knowledge combined with questionable methodology. Punitive damages are of special interest because they play a prominent role in the Chamber's results. The survey's accuracy is also testable by respondents' reaction to Delaware's receptivity to asbestos cases leading to Delaware being placed on a judicial hellhole watchlist.

This section first describes the central role of punitive damages in the survey and then documents problems with the survey's treatment of punitive damages, class actions, and judicial hellhole designation.

\section{A. The Importance of Punitive Damages}

Punitive damages play a, if not the, most visible role in the Chamber's rankings. Statements about what issues are important as well as statistical analysis of what influences the state rankings both establish punitive damages' importance.

In 2002, the Chamber presented the information in Table 2, Panel A, as identifying issues of prime concern. ${ }^{28}$ Punitive damages were the specific issue of greatest concern, just after the nonspecific issue of general tort reform. The gap between punitive damages and the issue of next greatest concern, judicial competence, was wide. Punitive damages continued to play a prominent role in the 2003 through 2007 surveys, and remained prominent in the 2008 survey. Table 2, Panel B, based on a table in the Chamber's 2008 survey, ${ }^{29}$ shows that punitive damages again ranked second in importance.

\footnotetext{
${ }^{28} 2002$ Survey at 15 .

${ }^{29} 2008$ Survey at 8.
} 
Figure 1: Distributions of Chamber's survey elements, 2002.

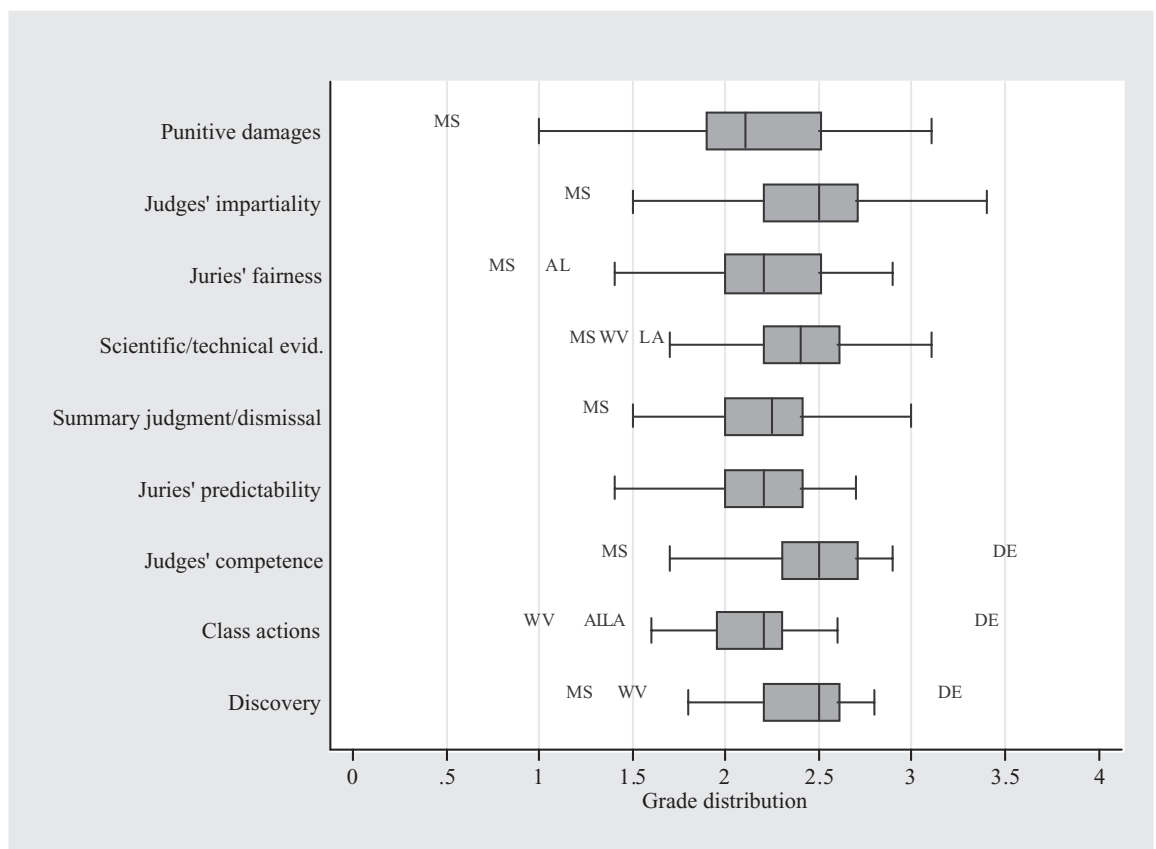

NoтE: Box plot of individual survey elements. For each element ranked in the 2002 Survey, the figure shows the 25th and 75 th percentiles, the median, the upper and lower adjacent values, and the data points more extreme than the adjacent values. The separation between the 25th and 75 th percentiles and for the lower and upper adjacent values is greatest for punitive damages. State postal abbreviations show outliers.

Another perspective on the data confirms the importance of punitive damages to survey respondents. The Chamber's survey give states an overall grade and rank by combining states' grades across surveyed elements. When rankings are based on aggregation across several factors, the most variable factors most influence the rankings. For example, suppose students take courses from five teachers, and an overall grade point average is computed from the courses (the factors). Students are then ranked based on the grade point averages. Assume that four of the teachers give all the students a grade of $\mathrm{B}$. The fifth teacher varies the grades, with a range from A to $\mathrm{F}$. The fifth teacher will completely determine a student's rank because that teacher provides all the variability in grades. The component of an aggregate ranking that varies the most will have a potent influence on the overall ranking.

Figure 1 shows the distribution of survey responses for each element of the Chamber's 2002 survey. The box plots in the figure display the grade distribution for each survey element. The figure indicates the elements along its left vertical axis. The left and right borders of the boxes for each element correspond to the 25th and 75th percentile grades cumulated for all states. For example, the 25th percentile for the element "Juries' fairness" was 2.0 (corresponding to a grade of $\mathrm{C}$ ). The lines within the boxes indicate the 50th 
percentile (or median). For example, the median numerical grade for "Judges' competence" was 2.5.

The ends of the "whiskers" extending to the left and right of the boxes indicate what are referred to as the upper and lower adjacent values. They are based on the interquartile range, which is the 75 th quartile grade minus the 25 th quartile grade. The adjacent values are the most extreme values within 1.5 times the interquartile range of the nearer quartile. The points beyond the ends of the whiskers, which are labeled in the figure using states' postal abbreviations, are outliers in that they are more extreme than the adjacent values.

The figure shows that the separation between the 25th and 75th percentiles (the width of the boxes) and the spread in responses represented by the whiskers was greatest for punitive damages. This indicates that states' rankings for punitive damages likely contributed more than other graded elements to the overall grade and ranking. The importance of punitive damages persists over time. In the 2008 survey, only juries' fairness competed with punitive damages for the largest spread. ${ }^{30}$ Figure 1 also shows that only five states appear as outliers for any element in 2002: Alabama, Delaware, Louisiana, Mississippi, and West Virginia. In 2008, the same five states were the sole outliers, except that Massachusetts was an additional positive outlier with respect to scientific and technical evidence. This consistency of extreme responses for a few states is discussed in Section V below.

\section{B. Erroneous Treatment of Punitive Damages and Class Actions}

Given the importance of punitive damages, the Chamber's survey should be especially careful to evaluate the topic. Yet the Chamber's treatment of the topic ranges from merely negligent to possibly overtly biased.

The merely negligent treatment of punitive damages is due to the Chamber's and/or its respondents' inaccurate knowledge of states' punitive damages laws. The Chamber has treated New Hampshire as having punitive damages when a substantial consensus exists that the state generally does not have them. For all years prior to 2008, the Chamber treated New Jersey as not having punitive damages when it does. The Chamber continues to treat Massachusetts as not having punitive damages when it does have them.

\section{New Hampshire Punitive Damages Law}

In its 2002 survey, the Chamber ranked New Hampshire 14th among states with respect to punitive damages. ${ }^{31}$ New Hampshire's black-letter law with respect to punitive damages is simple: "This jurisdiction forbids the award of punitive damages."32 In 2002, the Chamber's first survey year, the Supreme Court of New Hampshire reiterated that "New Hampshire

\footnotetext{
${ }^{30}$ In the 2002 survey, both had interquartile ranges of 0.4 and standard deviations of 0.33 .

${ }^{31} 2002$ Survey at 21 .

${ }^{32}$ Panas v. Harakis, 529 A.2d 976, 986 (N.H. 1987), quoting Fay v. Parker, 53 N.H. 342, 382 (1872). "However, when the act involved is wanton, malicious, or oppressive, the compensatory damages awarded may reflect the aggravating circumstances." Panas v. Harakis, 529 A.2d at 986, quoting, Vratsenes v. N.H. Auto, Inc., 289 A.2d 66, 68 (1972).
} 
does not permit recovery of punitive damages in personal injury cases." ${ }^{33}$ In the context of a driving-while-intoxicated case, a New Hampshire Superior Court judge has recognized that New Hampshire is "out of step with the majority of states" in not allowing punitive damages. ${ }^{34}$ Where a trial court reduced a jury award on the ground that it determined part of the award to be punitive in nature, the Supreme Court of New Hampshire approved a remittitur. ${ }^{35}$ The American Tort Reform Association acknowledges that New Hampshire effectively does not allow punitive damages. ${ }^{36}$ The Chamber itself effectively conceded its mistreatment of the issue because after 2003 the survey does not treat New Hampshire as having punitive damages. ${ }^{37}$ The Chamber does not expressly acknowledge its erroneous treatment of New Hampshire with respect to punitive damages.

\section{New Jersey Punitive Damages Law}

The Chamber's 2002 through 2007 surveys state that New Jersey does not award punitive damages in general. But New Jersey does authorize punitive damages.$^{38}$ Empirical data show that punitive damages are not rare events in New Jersey when requested and plaintiffs win at trial. ${ }^{39}$ The Chamber effectively admitted this error, not by expressly acknowledging the mistreatment of the state, but by finally changing New Jersey's treatment in the 2008 survey.

The treatment of punitive damages in New Jersey reinforces the evidence from the punitive damages treatment in New Hampshire. From 2002 through 2007, over 800 survey respondents reported themselves to be somewhat or very familiar with New Jersey law. Yet apparently not a single respondent knew enough or cared enough to inform the Chamber that it was erroneously describing New Jersey law.

\section{Massachusetts Punitive Damages Law}

The Chamber's 2002 through 2008 surveys state that Massachusetts does not allow punitive damages in general. The surveys oversimplify Massachusetts law. In cases of wrongful death

\footnotetext{
${ }^{33}$ In re Wintle, 781 A.2d 995, 997 (N.H. 2001), citing Aubert v. Aubert, 529 A.2d 909 (1987). In an action based on federal law, an insurer can be liable for punitive damages. American Home Assurance Co. v. Fish, 451 A.2d 358, 360 (N.H. 1982).

${ }^{34}$ Hanscom v. O'Connell, 2003 WL 23305265, at*4 (N.H. Super. 11/7/2003).

${ }^{35}$ DeBenedotto v. CLD Consulting Eng'rs, Inc., 903 A.2d 969, 985 (N.H. 2006).

${ }^{36}$ American Tort Reform Association, Punitive Damages Reform, http://www.atra.org/show/7343, accessed 6/20/ 2009. Some New Hampshire statutes authorize punitive damages but that has not altered the consensus view of New Hampshire being a state without punitive damages. Illustrative statutes are N.H. Rev. Stat. § 147-A:12 (wrongful discharge of whistleblowers who report hazardous waste violations); N.H. Rev. Stat. § 167:61 (punitive damages for false welfare claims of up to three times the excess benefit).

${ }^{37}$ E.g., ILR, http://www.instituteforlegalreform.com/states/pdf/NewHampshire.pdf, accessed 6/21/2009 (stating "New Hampshire does not allow punitive damages in general.").

${ }^{38}$ N.J. Stats Ann. 2A:15-5.12(a).

${ }^{39}$ Theodore Eisenberg, Michael Heise, Nicole L. Waters \& Martin T. Wells, The Decision to Award Punitive Damages: An Empirical Study (draft) (data only available for a subset of counties).
} 
or discrimination, Massachusetts law authorizes punitive damages. ${ }^{40}$ Both these areas are presumably of prime interest to the Chamber's members. In practice, punitive damages have been awarded in Massachusetts cases, though seemingly not at as high rates as in other states. ${ }^{41}$

Incorrectly characterizing punitive damages law is understandable and may be innocent legal analytic negligence. But the Chamber's failures to expressly acknowledge its errors, or even to award a grade to states that do not have punitive damages, is at best incompetent methodology and at worst intentional distortion. As shown above, punitive damages arguably have been the issue of most concern to survey respondents. States that do not allow punitive damages self-evidently should receive high grades from respondents on the punitive damages question.

\section{Assessing the Survey's Results When Objective Benchmarks are Available}

Punitive damages also provide an opportunity to objectively assess the relation between respondents' answers and the state of the law. Two other developments permit similar assessment. The Chamber warned a state of its appearance on a judicial hellhole watchlist, thus seemingly establishing that the state should decline in the rankings. The survey's treatment of class actions allows comparison of the state of the law with survey responses.

\section{Punitive Damages}

The Chamber's 2002-2003 erroneous treatment of New Hampshire with respect to punitive damages opens a rare window into the Chamber's respondents' actual knowledge of the states they rank. Since the Chamber treated New Hampshire as having punitive damages in 2002 and 2003, it published the responses for those years. New Hampshire's grades for punitive damages for these years are capable of objective evaluation and respondents almost always graded incorrectly.

According to the Chamber, New Hampshire's "Mean Grade" for punitive damages in 2002 was 2.4. ${ }^{42}$ That is the same grade that New Hampshire received for "Overall Treatment of Tort and Contract Litigation." It is a notch below New Hampshire's "Overall State Grade" of 2.5. The Chamber's respondents thus gave New Hampshire a lower grade on punitive damages than the state's overall grade despite New Hampshire's prohibition of punitive damages. Fourteen percent of the 2002 New Hampshire respondents gave the state a D or F with respect to punitive damages, a remarkable performance for a group that is supposed to be informed about the state. Only seven of 63 respondents gave New Hampshire an A with respect to punitive damages. In 2003, New Hampshire's 2.5 mean grade on punitive damages was again below the state's overall treatment, which received a grade of 2.6. And

\footnotetext{
${ }^{40}$ Mass. Gen. Laws Ann. $229 \S 2$ (wrongful death); Mass. Gen. Laws Ann. 151B $§ 9$ (punitive damages); Gasior v. Massachusetts Gen. Hosp., 846 N.E.2d 1133, 1140 (Mass. 2006).

${ }^{41}$ Eisenberg et al., supra note 39 .

${ }^{42} 2002$ Survey at 58.
} 
only one respondent in 39 gave New Hampshire the presumably proper grade of A. For the two years combined, the Chamber's respondents gave New Hampshire the correct A grade in only eight out of 102 responses. Less than 10 percent of the respondents had sufficient knowledge of New Hampshire law to get a central feature of its law right.

The Chamber admits that the proper punitive damages grade for New Hampshire and other nonpunitive damages states should be the highest ranking. In its 2007 survey, the Chamber recognized this by assigning states without punitive damages "the highest score achieved from other states on punitive damages (i.e., Delaware's)." ${ }^{43}$ This is in a sense too low a ranking because the nonpunitive damages states deserve a higher ranking than Delaware, which clearly allows punitive damages. ${ }^{44}$ The Chamber claims that the alternative measure has not affected the rankings. But this claim is not credible for all years. For example, giving Louisiana an A for punitive damages in the 2002 survey would have moved it up in the rankings, as would an A in the 2003 survey.

Delaware's and New Jersey's treatment with respect to punitive damages is additional evidence that respondents lack elementary knowledge of states they rank. Table 1 shows Delaware ranked first for punitive damages in 2002 and 2008, ahead of all states that do not have punitive damages (Louisiana, Nebraska, New Hampshire, and Washington). Delaware courts have approved punitive damages awards of at least $\$ 10$ million $^{45}$ and a punitivecompensatory ratio of almost ten to one, ${ }^{46}$ well above a national aggregate ratio. ${ }^{47} \mathrm{New}$ Jersey courts not infrequently award punitive damages, yet, as noted above, over 800 survey respondents failed to correct the Chamber's mistreatment. As in the case of New Hampshire, the Chamber's respondents appear to have almost no knowledge of states they ranked. The New Jersey results support the New Hampshire based finding that less than 10 percent of respondents have acceptable knowledge of the state legal systems they evaluate.

\section{Judicial Hellholes}

A second instance of objectively verifiable information comes from an incident in the Chamber's most highly ranked state, Delaware. In 2006, the Delaware Superior Court rendered an asbestos litigation decision that the Chamber found unacceptable. In 2005 many out-of-state asbestos cases were filed in the court and the corporate defendants argued against hearing the cases and moved to dismiss them. ${ }^{48}$ On March 8, 2006, the court

\footnotetext{
${ }^{43} 2007$ Survey at 18.

${ }^{44}$ E.g., Galindez v. Narragansett Housing Assocs., L.P., 2006 WL 3457628 (Del. Super. 11/28/2006) (approving \$10 million punitive award).

${ }^{45}$ Galindez v. Narragansett Housing Assocs., L.P., supra.

${ }^{46}$ Jones v. Delaware Comty. Corp. for Individual Dignity, 2004 WL 2827924 (Del. Super. 4/29/2004).

${ }^{47}$ Exxon Shipping Co. v. Baker, 128 S. Ct. 2605, 2624 (2008) (median ratio is about 1:1).

${ }^{48}$ Kirk et al., supra note 18.
} 
refused to dismiss them. ${ }^{49}$ On November 1, 2007, the President of the Delaware Chamber of Commerce wrote to the Presiding Judge of the Delaware Superior Court expressing concern about Delaware's receptivity to many toxic-tort personal injury cases. The letter suggested that Delaware was in danger of descending into judicial hellhole status. The threat embodied in the letter was described as follows by the Special Committee Delaware appointed to investigate the concerns:

In its letter, the Chamber noted Delaware's appearance in reports of the American Tort Reform Foundation (ATRF) on a "Watch List" for potential "Judicial Hellholes." ATRF publishes an annual list of what it considers "Judicial Hellholes," which it says "are places where judges systematically apply laws and court procedures in an unfair and unbalanced manner, generally against defendants in civil lawsuits." For the past two years, ATRF has placed Delaware on its "Watch List," which ATRF reserves for "jurisdictions [showing] suspicious or negative developments in the litigation environment or histories of abuse." 50

So in 2007, Delaware was on a list of potential judicial hellholes. ${ }^{51}$ In 2007, Madison County, Illinois was on the same list as Delaware ${ }^{52}$ but that county was singled out by the Chamber's respondents as having one of the least fair litigation environments in the country. ${ }^{53}$

A state added to the list should suffer in its Chamber ranking since many states are not on that list. One therefore would have expected Delaware's overall rank and rank in survey elements to decline during this time period. Yet in 2005, 2006, and 2007 Delaware ranked first in "Overall Treatment of Tort and Contract Litigation." ${ }^{54}$ Delaware's rank for another element related to accepting non-Delaware asbestos actions ${ }^{55}$ should also have been affected. Beginning in the 2006 survey, the Chamber asked respondents to rank states for "Having and Enforcing Meaningful Venue Requirements." A state on a judicial hellhole watchlist for accepting tort suits unrelated to the state should rank low for this element. Yet

\footnotetext{
${ }^{49}$ Id. at i.
}

${ }^{50}$ Id. at 1 n.1. Despite the Delaware Committee's finding that the asbestos ruling was fair, the Chamber's tactics may have their intended effect. Delaware judges now know that if they rule in a way the Chamber does not like their ruling may be the subject of a special committee investigation.

\footnotetext{
${ }^{51}$ American Tort Reform Foundation (ATRF), Judicial Hellholes 2007, at iv.
}

${ }^{52}$ Ann Knef, Madison County Ascends from ATRA's "Hellhole," The Madison-St. Clair Record, 12/18/2007. Madison County was removed from a list of most unfair jurisdictions not by virtue of a systematic assessment of the outcome of cases, but because Madison County jurors reportedly delivered five defense verdicts in a week. Knef, supra. Chamber members did not get the message as they ranked Madison County as the fifth most unfair and unreasonable local jurisdiction in 2008. 2008 Survey at 9. For evidence about the actual pattern of case outcomes in Madison County, see Neil Vidmar et al., "Judicial Hellholes": Medical Malpractice Claims, Verdicts and the "Doctor Exodus" in Illinois, 59 Vand. L. Rev. 1309 (2006).

${ }^{53} 2007$ Survey at 8; 2008 Survey at 9.

542005 Survey at 21; 2006 Survey at 26; 2007 Survey at 14.

${ }^{55}$ The Chamber's letter to Delaware's Superior Court expressed concern about filings "by out-of-state law firms on behalf of out-of-state plaintiffs whose claims have no meaningful connection to Delaware." Kirk et al., supra note 18, at 1 . 
in 2006 Delaware ranked second ${ }^{56}$ In 2007, the year Delaware was informed of its pending judicial hellhole status, Delaware ranked third. ${ }^{57}$ Respondents apparently had little knowledge of activity in Delaware but nevertheless graded the state.

\section{Class Actions}

Another objectively verifiable grade is Mississippi's for class actions. From 2002 through 2005, the Chamber graded states on class actions. It did not report the respondents' answers for Mississippi on the ground that Mississippi did not have class actions. ${ }^{58}$ From 2006 through 2008, the Chamber asked a combined question about class actions and aggregate litigation. Mississippi ranked in the bottom four states on this element in all three years even though Mississippi does not have class actions. ${ }^{59}$

At best, the Chamber created an untenable category on which to grade Mississippi. If the state was not gradable on class actions through 2005, it did not become gradable in the combined class actions/aggregate litigation element in 2006 through 2008 since it was not gradable on one part of the combined element. Mississippi could only receive an A on class actions since it does not allow them. But the Chamber did not allow respondents' to give a presumed grade of A for Mississippi in class actions, and whatever grade respondents wished on a non-class-action litigation element. The Chamber's combined element provided respondents' grades only in years in which Mississippi's class actions grade was undisclosed and uncounted because the grade was embedded in the aggregate element.

New Jersey's large decline in rank in 2008 provides an opportunity to assess respondents' knowledge of case law relating to class actions. In 2007, New Jersey ranked 14th in class actions ${ }^{60}$ In 2008, it ranked 35 th, ${ }^{61}$ a 21-place decline and among the largest declines of any state in any year. What happened to class action doctrine in New Jersey to cause the decline? Without access to the data or to the respondents one cannot know for sure. But one can evaluate whether New Jersey reasonably should have been expected to substantially decline from its 2007 rank by reviewing available New Jersey class action decisions for the period relevant to the Chamber's 2008 Survey interviews.

The Chamber's 2008 Survey was based on interviews between December 18, 2007 and March 19, 2008 ${ }^{62}$ and the 2007 Survey was based on interviews between December 27, 2006

\footnotetext{
${ }^{56} 2006$ Survey at 25 .

${ }^{57} 2007$ Survey at 15 .

${ }^{58}$ E.g., 2005 Survey at 56.

${ }^{59} 2006$ Survey at 27; 2007 Survey at 16; 2008 Survey at 17.

${ }^{60} 2007$ Survey at 16 .

${ }^{61} 2008$ Survey at 17.

${ }^{62}$ Id. at 27 .
} 
Table 3: New Jersey Class Action Opinions During Period of Chamber's 2008 Survey

\begin{tabular}{|c|c|c|c|}
\hline Date & Case Name, Citation & Ruling & $\begin{array}{l}\text { Ruling Limits } \\
\text { Class Actions }\end{array}$ \\
\hline $1 / 15 / 08$ & $\begin{array}{l}\text { Santomenno v. Allmerica Fin. } \\
\text { Corp., } 2008 \text { WL } 123920\end{array}$ & $\begin{array}{l}\text { Affirmed summary judgment } \\
\text { dismissal of purported class } \\
\text { action. }\end{array}$ & yes \\
\hline $9 / 6 / 07$ & $\begin{array}{l}\text { Int'l Union of Operating } \\
\text { Eng'rs v. Merck \& Co., } 929 \\
\text { A.2d } 1076 \text { (N.J.) }\end{array}$ & $\begin{array}{l}\text { Reversed certification of } \\
\text { nationwide class of } \\
\text { third-party payors in Vioxx } \\
\text { action. }\end{array}$ & yes \\
\hline $8 / 10 / 07$ & $\begin{array}{l}\text { Buynie v. Airco, Inc., } 2007 \text { WL } \\
2275013\end{array}$ & $\begin{array}{l}\text { Affirmed order denying class } \\
\text { certification of medical } \\
\text { monitoring claim. }\end{array}$ & yes \\
\hline $7 / 31 / 07$ & $\begin{array}{l}\text { In re Vioxx Litig., } 928 \text { A.2d } \\
\quad 935\end{array}$ & $\begin{array}{l}\text { Affirmed dismissal of } 98 \text { U.K. } \\
\text { Vioxx claims on grounds of } \\
\text { forum non conveniens. }\end{array}$ & yes \\
\hline $6 / 22 / 07$ & $\begin{array}{l}\text { Beegal v. Park W. Gallery, } 925 \\
\text { A.2d } 684\end{array}$ & $\begin{array}{l}\text { Reversed certification of } \\
\text { nationwide class action } \\
\text { against cruise ship } \\
\text { company. }\end{array}$ & yes \\
\hline $5 / 31 / 07$ & $\begin{array}{l}\text { Iliadis v. Wal-Mart Stores, Inc., } \\
922 \text { A.2d } 710 \text { (N.J.) }\end{array}$ & $\begin{array}{l}\text { Reversed denial of class } \\
\text { certification of claim that } \\
\text { employees were required to } \\
\text { work off the clock. }\end{array}$ & no \\
\hline $5 / 22 / 07$ & $\begin{array}{l}\text { Hannan v. Weichert S. Jersey, } \\
\text { Inc., } 2007 \text { WL } 1468643\end{array}$ & $\begin{array}{l}\text { Affirmed denial of class } \\
\text { certification. }\end{array}$ & yes \\
\hline $3 / 30 / 07$ & $\begin{array}{l}\text { Chandelaria v. Rent-A-Center, } \\
2007 \text { WL } 935584\end{array}$ & $\begin{array}{l}\text { Affirmed denial of leave to } \\
\text { amend complaint to assert a } \\
\text { class action. }\end{array}$ & yes \\
\hline $3 / 10 / 07$ & $\begin{array}{l}\text { Chadwick } 99 \text { Assocs. v. } \\
\text { Director, Div. of Taxation, } \\
23 \text { N.J. Tax } 390\end{array}$ & $\begin{array}{l}\text { Refused to certify class action } \\
\text { in tax matter. }\end{array}$ & yes \\
\hline $3 / 7 / 07$ & $\begin{array}{l}\text { Muise v. GPU, Inc., } 917 \text { A.2d } \\
261\end{array}$ & $\begin{array}{l}\text { Reversed decertification of } \\
\text { class to allow utility } \\
\text { customers time to present } \\
\text { proof of damages. }\end{array}$ & no \\
\hline
\end{tabular}

NotE: Decisions were in N.J. Superior Court unless citation indicates otherwise.

Source: Online searches for New Jersey class action decisions from March 2, 2007 and before March 19, 2008.

and March 2, 2007. ${ }^{63}$ So the most relevant cases for assessing New Jersey's drop from 2007 to 2008 were decided after March 2, 2007 and before March 19, 2008. Table 3 lists the relevant class action cases I was able to locate using online searches. While this may not be a complete list of class action decisions in New Jersey, it is a reasonable sample of cases in which New Jersey courts articulated class action doctrine through written opinions. The results of the doctrine-shaping class action cases suggest, if anything, a case law pattern

${ }^{63} 2007$ Survey at 26. 
moving against certification of class actions or aggregate litigation in New Jersey. Of the 10 decisions in the table, eight favored the Chamber's anti-class action/aggregate litigation views and two did not.

Aside from a 4:1 ratio favoring the Chamber's views, two of the decisions are noteworthy because of their special visibility and New Jersey's important role in Vioxx litigation. ${ }^{64}$ In one case in Table 3, New Jersey's Supreme Court reversed certification of a nationwide class of third-party payors against Merck \& Co., Inc. based on death and injuries resulting from Vioxx. In another case, a New Jersey appellate court affirmed dismissal of 98 U.K. Vioxx claims on grounds of forum non conveniens. Both of these decisions would be expected to find favor with the Chamber's respondents in the survey element "Treatment of Class Actions Suits and Mass Consolidation Suits." Yet, as noted, New Jersey dramatically declined in this category. ${ }^{65}$

The two decisions should have improved New Jersey's rank for another element. Class actions or aggregate litigation can bring nonresidents' cases into a state. As described above, Delaware risked judicial hellhole status by allowing nonresident asbestos cases in its courts. Since the two Vioxx decisions rejected New Jersey as a forum for out-of-state and out-of-country events, these two rulings might be expected to produce an improved rank for New Jersey for the survey element "Having and Enforcing Meaningful Venue Requirements." But New Jersey also plummeted in that category to 39th from its 26th place ranking in 2007.

\section{What Explains the Rankings?}

Respondents' rankings are not driven by objectively ascertainable statutory or case law. Respondents graded correctly less than 10 percent of the time for grades verifiable by statutory law. And respondents apparently did not rank New Jersey based on what occurred in class action decisions. Nor are the rankings explicable by the Chamber's sense of where courts may be failing. Delaware's consistently high rank is inconsistent with its judicial hellhole watchlist status. ${ }^{66}$ If respondents do not rank on ascertainable law, they are responding to other stimuli and this section explores that possibility.

This section first shows the relation across elements of the grades given by Chamber respondents. The relation is strikingly consistent, suggesting that only a single impression

\footnotetext{
${ }^{64}$ See text accompanying notes $110-118$, infra.
}

${ }^{65}$ On January 16, 2007, in Sinclair v. Merck $\mathcal{E}$ Co., 913 A.2d 832 (N.J. Super. 2007), a New Jersey Superior Court reversed dismissal of a medical monitoring class action against Merck but offered no opinion concerning the ultimate viability of the class action. On review on June 4, 2008, the Supreme Court of New Jersey dismissed the medical monitoring suit filed by Vioxx plaintiffs. 948 A.2d 587 (N.J. 2008).

\footnotetext{
${ }^{66}$ Counsel for large corporations may systematically overrank Delaware. Large corporations tend to incorporate in Delaware and counsel for these corporations, the Chamber's primary respondents, presumably approve of Delaware's laws regulating corporate governance. E.g., Theodore Eisenberg \& Geoffrey P. Miller, The Flight to New York: An Empirical Study of Choice of Law and Choice of Forum Clauses in Publicly-Held Companies' Contracts, 30 Cardozo L. Rev. 1475, 1476 (2009).
} 
about a state drives a state's grades for all elements. The section then suggests that a state's grades are driven largely by (1) respondents' negative historical reaction to a few states, including all Gulf Coast states, that played prominent roles in the history of modern tort litigation, and respondents' inability to change views in light of changed events, and (2) respondents' failure to distinguish between absolute levels of activity and rates of activity, resulting in unwarranted low rankings of populous states. Respondents' failure to recognize that more events they dislike are likely to occur in more populous states may explain New Jersey's otherwise puzzling decline in rank.

\section{A. Evidence that a Single Latent Factor Determines Rankings}

To explore the interelement pattern of the Chamber's respondents' rankings, it is helpful to visualize the relation among the graded elements. Figure 2 is a matrix of scatterplots of the association between each of the graded elements in 2008. For example, the first graph in the upper left of the figure shows the scatterplot for the relation between a state's overall tort and contract litigation grade and its grade for class actions. Each point in the scatterplot represents a state's score on these two elements.

The figure shows high correlations among the graded elements. For the 66 bivariate relations between two Chamber elements represented in Figure 2, correlation coefficients (which can range from -1.0 to +1.0 ) between elements are never less than 0.68 , only one is less than 0.75 , and most are in the neighborhood of $0.8,0.9$, and greater. All of the linear correlations are statistically significant at $p<0.0001$. The Chamber has acknowledged that its ranking elements are highly correlated. ${ }^{67}$

The correlation pattern suggests using the statistical method known as factor analysis to assess how many latent independent factors the Chamber's multiple elements represent. ${ }^{68}$ Confirmatory factor analysis supports what the figure suggests-although the Chamber ranks on many elements, only a single latent factor is at work for a state. ${ }^{69}$

The high interelement correlations suggest not only that one factor is at work but also further calls into question the respondents' knowledge of individual survey elements. It is implausible that states line up so uniformly across all queried elements. Table 1 shows extreme uniformity, with the 2002 survey ranking Delaware first in all categories. The state's high rank survived its later placement on the hellhole watchlist since Delaware has ranked first overall in every year of the survey. Figure 1 shows that only Delaware achieved positive outlier status with respect to any element. Delaware ranking first with respect to punitive damages, ahead of all states that have no punitive damages, further suggests that respondents respond to individual survey elements based on a single latent factor about a state

\footnotetext{
${ }^{67} 2008$ Survey at 3 n.2; 2007 Survey at 2 n.2 ("All of the key element items were highly correlated with one another and with overall performance.”); 2006 Survey at 7. ${ }^{68}$ Factor analysis assesses variability among a group of observed variables in terms of fewer unobserved variables called
factors. Richard L. Gorsuch, Factor Analysis (2d ed. 1983).

${ }^{69}$ See, e.g., Ke-Hai Yuan \& Peter M. Bentler, Mean and Covariance Structure Analysis: Theoretical and Practical Improvements, 92 J. Am. Statistical Assoc. 767 (1997).
} 


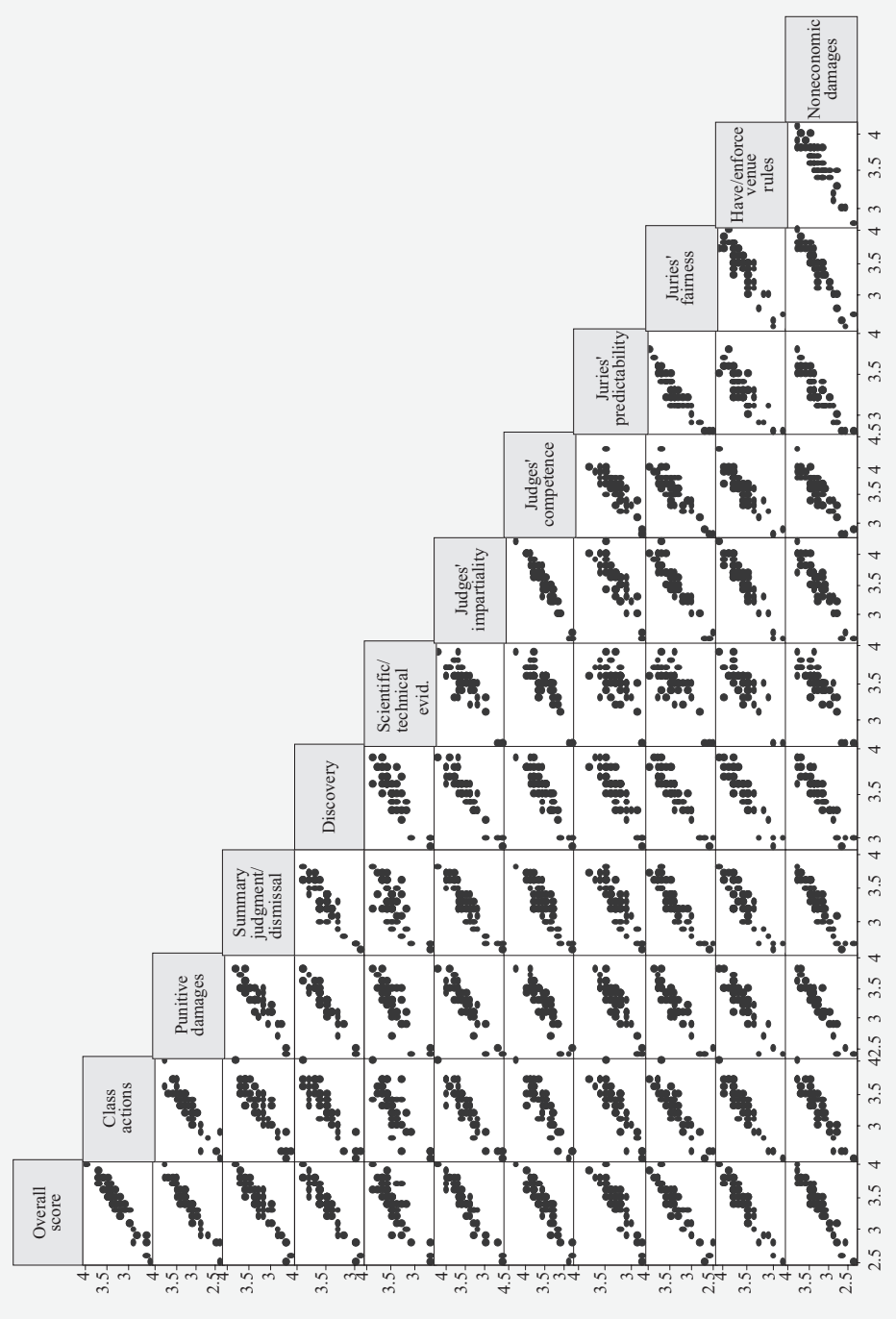


rather than based on knowledge of elements for each state. No valid ranking could have Delaware first with respect to punitive damages. And large companies tend to choose New York, not Delaware, as a forum and as a choice of law in their contracts. ${ }^{70}$ Yet in 2008 New York ranked 25th overall compared to Delaware's first.

The single latent factor likely exists for low-ranked states as well as for high-ranked Delaware. When respondents disapprove of a state, the state tends to rank low in all categories. For example, in the 2008 survey, neither Mississippi nor Louisiana is ranked higher than 47 th in any category. Figure 1 shows that in the 2002 survey only the same four states achieved negative outlier status with respect to any element. The within-state variation across element grades is also strikingly small. In the 2008 survey, no state's grade on any element differed from its grade on any other element by even as much as one grade level. For example, if the state had a mean grade of 3.5 on one element it never got more than a 4.3 or less than a 2.7 on any other element.

When a state swings wildly in the Chamber's ranking from year to year, it tends to do so across many elements, again suggesting a single factor drives grades. Tennessee's overall ranking moved from 29th in 2006, up to 7 th in 2007, and then down to 22nd in $2008 .{ }^{71}$ These large swings are implausible and become less so upon inspecting individual elements. In 2007, Tennessee was ranked in the top five states for the following elements: "Having and Enforcing Meaningful Venue Requirements" (4th); "Treatment of Class Action Suits and Mass Consolidation Suits" (2nd); "Punitive Damages" (3rd); "Noneconomic Damages" (5th); and "Juries Predictability" (4th). ${ }^{72}$ In 2008, Tennessee's rankings for these elements were, respectively: $29 \mathrm{th}, 27 \mathrm{th}, 15 \mathrm{th}, 27 \mathrm{th}$, and $33 \mathrm{rd} .{ }^{73}$ Substantial movement within some elements is utterly implausible. Vermont's judges, for example, ranked 29th for impartiality and 26th for competence in $2007 .{ }^{74}$ In 2008, they ranked 7th and 10th, respectively. ${ }^{75}$ Colorado's judges moved from the 9 th most competent to the 25th most competent in a single year. ${ }^{76}$ Judiciaries tend to not turn over quickly enough and judges' behavior across entire states does not swing wildly enough to support such shortterm massive changes. Vast movement across many elements in a single year and across particular elements suggests that respondents lack knowledge of individual elements and rank on a single impression of a state.

Despite the lack of within-state variation in a year, the question remains: What might drive a state's ranking? The most plausible measure may be that the respondents provide a

\footnotetext{
${ }^{70}$ Eisenberg \& P. Miller, supra note 66.

${ }^{71} 2008$ Survey at 7.

${ }^{72} 2007$ Survey at $11-13$.

${ }^{73} 2008$ Survey at $16-18,22,25$.

${ }^{74} 2007$ Survey at 22-23.

${ }^{75} 2008$ Survey at $23-24$.

762006 Survey at 34; 2007 Survey at 23.
} 
Figure 3: State overall tort and contract grade, 2008.

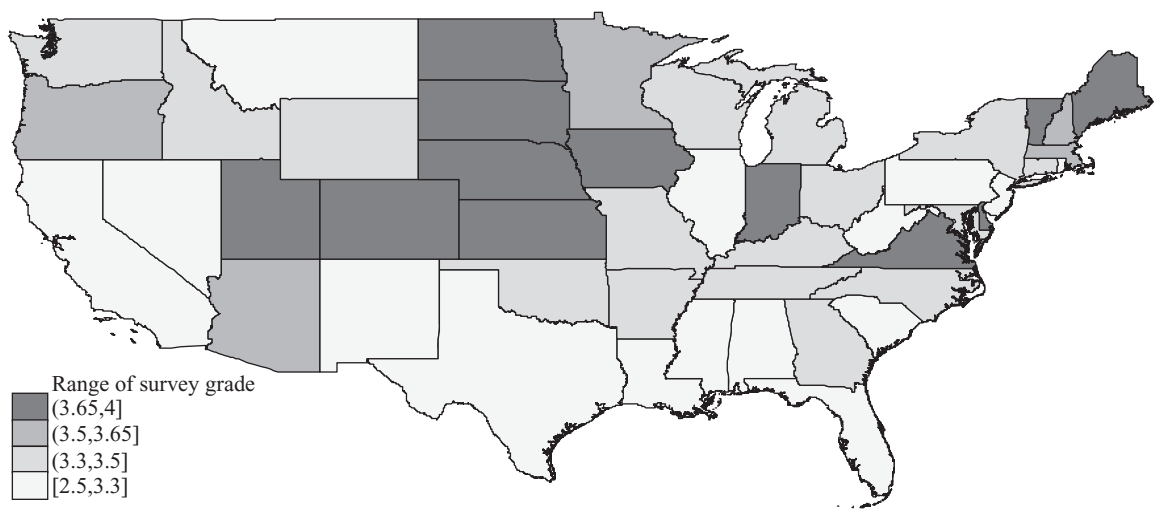

NoTE: The map shows shading corresponding to the 2008 survey grade for each state for the element "Overall Treatment of Tort and Contract Litigation." Alaska and Hawaii are not shown. Source: 2008 Survey.

measure of large corporations' overall faith in a state court system. If that is the factor represented, one should expect an association between the Chamber's ranking and the rate at which corporations opt out ex ante from the court systems when they have an opportunity to do so. Since large corporations may opt out of court systems through ex ante agreements to arbitrate, there should be an association between a state's ranking and the rate at which arbitration clauses are used in contracts of large corporations connected to the state. Yet that association has not been detected to exist; the relation between ranking and arbitration clause use appears to be random. ${ }^{77}$ The respondents' rankings are thus inconsistent with their own corporations' behavior.

Some insight into the source of the Chamber's respondents' grade pattern emerges from the data map in Figure 3, which shows in its lightest shade the states the Chamber ranks lowest. At least three observations are worth noting based on the figure. First, low rankings are only partially tied to states associated with one political party or another. Both liberal and conservative states incur respondents' displeasure. But the Chamber's strongest approval, signified by those states with the darkest shading, is largely reserved for more conservative states, except for the low population states of Vermont and Maine. Second, every one of the five Gulf Coast states fares poorly in the Chamber's study. In 2008, for example, the mean overall tort and contract ranking for Gulf Coast states was 2.92 compared to 3.47 for other states, a statistically significant difference ( $p=0.002$; Mann-Whitney test). Third, no state with a relatively large population obtains high ratings from the Chamber. Virginia, the 11th largest state by population, is the most populous state receiving strong Chamber approval.

\footnotetext{
${ }^{77}$ Theodore Eisenberg \& Geoffrey P. Miller, The Flight from Arbitration: An Empirical Study of Ex Ante Arbitration Clauses in Publicly-Held Companies' Contracts, 56 DePaul L. Rev. 335, 370-71 (2007).
} 
The political pattern seems readily explicable but the Gulf Coast and population effects less so. While any explanation without additional information about respondents and about actual case outcomes in states is somewhat speculative, the latter two effects may be tied to heuristics that preclude the Chamber's biased sample of corporate respondents from accurately processing information.

\section{B. The Gulf Coast-Tobacco Effect}

Gulf Coast states have played a prominent role in the modern history of big-stakes tort litigation. In the 1980s and somewhat earlier, a fairly small number of large asbestos disputes resulted in large awards. ${ }^{78}$ Due to the location of shipyards and other industries, workers poisoned by asbestos tended to be concentrated in Gulf Coast states. "In the early days of the litigation, cases were filed in about a dozen federal and state courts in coastal areas where shipyard workers had been heavily exposed to asbestos and in the gulf states where there had been heavy use of asbestos in petrochemical facilities." ${ }^{29}$ From 1993 to 2003, states with large-scale asbestos trial consolidations included Louisiana, Mississippi, and Texas. ${ }^{80}$ Florida has also been important in asbestos litigation. ${ }^{81}$

Several lawyers prominent in asbestos litigation then played a role in the largest settlement in litigation history, $\$ 246$ billion, embodied in the state attorneys general's tobacco cases' Master Settlement Agreement in $1998 .^{82}$ That litigation started in Mississippi and other Gulf Coast states-Florida, Texas, and Louisiana-played early and prominent roles. Another state that fares poorly in the Chamber's ranking, West Virginia, was one of the first five states to bring an action against the tobacco companies ${ }^{83}$ and has played a prominent role in asbestos litigation. ${ }^{84}$ South Carolina, another low-ranked state, had attorneys who played a prominent role in tobacco and asbestos litigation, ${ }^{85}$ including Ronald Motley, portrayed by actor Bruce McGill in the tobacco litigation movie, The

\footnotetext{
${ }^{78}$ William Haltom \& Michael McCann, Distorting the Law: Politics, Media, and the Litigation Crisis 167-68 (2004).

${ }^{79}$ Stephen J. Carroll, Deborah Hensler, Allan Abrahamse, Jennifer Gross, Michelle White, Scott Ashwood \& Elizabeth Sloss, Asbestos Litigation Costs and Compensation: An Interim Report 34 (RAND 2002). See also Stephen J. Carroll, Deborah Hensler, Jennifer Gross, Elizabeth M. Sloss, Matthia Schonlau, Allan Abrahamse \& J. Scott Ashwood, Asbestos Litigation 61 (RAND 2005) [hereinafter "RAND 2005"].
}

${ }^{80}$ RAND 2005, supra note 79, at 38-42

${ }^{81}$ Id. at 61 . None of the 11 states that RAND describes as quantitatively prominent in asbestos litigation, id. at 62 , is ranked highly in the Chamber survey.

\footnotetext{
${ }^{82}$ Master Settlement Agreement, available at the National Association of Attorneys General website, http:// www.naag.org/backpages/naag/tobacco/msa/msa-pdf/1109185724_1032468605_cigmsa.pdf, accessed 6/26/2009. ${ }^{83}$ Richard P. Ieyoub \& Theodore Eisenberg, State Attorney General Actions, the Tobacco Litigation, and the Doctrine
of Parens Patriae, 74 Tulane L. Rev. 1859, 1861, 1875-76 n.95 (2000).
}

${ }^{84}$ RAND 2005, supra note 79, at 29, 32, 34, 40-41.

${ }^{85}$ Id. at 32 n.31. 
Insider. ${ }^{86}$ The prominence of Gulf Coast attorneys in tobacco litigation enhanced the capital available to fund litigation by an increasingly visible group of plaintiffs' lawyers. ${ }^{87}$

So large corporations' counsel had been beaten badly by Gulf States' plaintiffs' lawyers, increasingly encountered well-funded adversaries in those states, and may have become disgruntled with those states. But their dissatisfaction does not necessarily equate with unfair treatment. Few people seriously defend the asbestos or tobacco industries' behavior $^{88}$ (though that of course does not mean that they should lose every lawsuit, and they do not ${ }^{89}$ ). Nevertheless, when people have strong prior attitudes on a subject, they have difficulty in updating those attitudes in light of objective or new evidence. ${ }^{90}$ The Chamber's responding lawyers, many of whom may have responded to the survey in more than one year, probably had corporate careers shaped by, or conducted in the shadow of, asbestos and tobacco litigation. Their or their mentors' hostility to Gulf Coast states, West Virginia, and South Carolina might be what the Chamber's surveys reflect rather than objective evaluation of elements within states.

Some states continuously ranked low have changed circumstances that are evidence against the Chamber's survey providing an objective evaluation. These states have dramatically changed their laws but the respondents' prior impressions are difficult to modify with new evidence. So when Texas enacted a slew of tort reforms ${ }^{91}$ and provided an opinion highly favorable to corporate defendants, ${ }^{92}$ the Chamber's respondents may simply have been incapable of modifying their views based on new developments. That Louisiana enacted pro-business statutes ${ }^{93}$ and prohibits punitive damages similarly had little effect on

\footnotetext{
${ }^{86}$ Internet Movie Database, The Insider, http://www.imdb.com/title/tt0140352/, accessed 6/26/2009.

${ }^{87}$ Michael Freedman, Tobacco Lawyers, http://www.forbes.com/forbes/2001/0514/134.html, accessed 6/26/2009.

${ }^{88}$ See, e.g., Paul Brodeur, Outrageous Misconduct: The Asbestos Industry on Trial (1985); Stanton A. Glantz, John Slade, Lisa A. Bero, Peter Hanauer \& Deborah E. Barnes, The Cigarette Papers (1996). But the wrongdoing is not all on one side. The misbehavior of some plaintiffs' counsel and experts in asbestos and silica litigation, see In re Silica Prods. Liab. Litig., 398 F. Supp. 2d 563 (S.D. Tex. 2005), may reinforce survey respondents' negative views of states prominently associated with asbestos cases.
}

${ }^{89}$ For information about tobacco trial win rates after the Master Settlement Agreement, see Theodore Eisenberg, Damage Awards in Perspective: Behind the Headline-Grabbing Awards in Exxon Valdez and Engle, 36 Wake Forest L. Rev. 1129 (2001).

\footnotetext{
${ }^{90}$ Charles G. Lord, Lee Ross \& Mark R. Lepper, Biased Assimilation and Attitude Polarization: The Effects of Prior Theories on Subsequently Considered Evidence, 37 J. Personality \& Soc. Psychol. 2098 (1979); Peter C. Wason, On the Failure to Eliminate Hypotheses in a Conceptual Task, 12 Q. J. Experimental Psychol. 129 (1960).
}

\footnotetext{
${ }^{91}$ American Tort Reform Association, http://www.atra.org/wrap/files.cgi/7964_howworks.html, accessed 6/25/
} 2009.

${ }^{92}$ Merrell Dow Pharm. v. Havner, 953 S.W.2d 706 (Tex. 1997) (limits on acceptable epidemiological evidence in pharmaceutical cases).

${ }^{93}$ NAMIC Report Details State Tort Reform Efforts, Insurance J., 1/9/2004, http:/ /www.insurancejournal.com/news/ national/2004/01/09/35533.htm, accessed 6/25/2009 (Louisiana, Texas, and Florida among the states that have passed the most tort reform statutes); http://www.namic.org/reports/tortreform/, accessed 6/25/2009. 
their views. Mississippi's pro-business statutes have had little effect on its rankings. ${ }^{94}$ West Virginia's legislature enacted caps on medical malpractice damages, limits on joint and several liability, restrictions on lawsuits by out-of-state plaintiffs, and elimination of thirdparty bad faith claims against insurance companies. ${ }^{95}$ Yet that state also continues to fare poorly in the Chamber's rankings. Under this view, the respondents are at least partly living in the past.

One caveat to the asbestos-tobacco explanation of rank is necessary. Alabama is a low-ranked Gulf Coast state whose rank is not readily explicable by asbestos and tobacco developments. RAND's study of asbestos litigation does not list Alabama as ever having relatively large numbers of asbestos cases or as being the site of a major consolidated asbestos trial. ${ }^{96}$ And, unlike other Gulf Coast states, Alabama decided not to be a major player in the state attorneys general tobacco litigation. ${ }^{97}$ Alabama's low Chamber rank seems more attributable to (1) the importance of punitive damages in the Chamber's survey, as shown in Section IV.A, (2) substantial punitive damages activity in Alabama, and (3) as in the case of other Gulf Coast states, respondents' inability to alter their views based on changed circumstances in a state.

Alabama has been repeatedly singled out for its treatment of punitive damages. ${ }^{98}$ Its reputation as being hostile to defendants in the 1990s was "based in substantial part on an increasing number of large punitive damage awards in Alabama courtrooms," 99 and the use of punitive damages in alleged fraud cases involving insurance companies. ${ }^{100}$ George Priest's 1996 study of three small Alabama counties, conducted in connection with litigation, reported punitive damages claims in over 70 percent of tort claims in the early 1990s. ${ }^{101}$ In 1987, Alabama's legislature enacted several tort reform measures; among those

${ }^{94}$ R. Neal, Tort "Reform" Around the South, 3/30/2006, The Institute for Southern Studies, http:// www.southernstudies.org/2006/03/tort-reform-around-south.html, accessed 6/25/2009.

${ }^{95}$ Thornburg, supra note 7 , at 1098-99.

${ }^{96}$ RAND 2005, supra note 79, at 38-41 (list of consolidated trials), 63 (list of courts with at least 2 percent of state court asbestos filings in any period).

${ }^{97}$ William H. Pryor Jr., William P. Gray Jr., John Wible, Peggy Schmitz \& Michael DeBow, Report of the Task Force on Tobacco Litigation Submitted to Governor James and Attorney General Sessions, October 2, 1996, 27 Cumberland L. Rev. 577 (1996-1997).

${ }^{98}$ E.g., Nathan C. Prater, Comment, Punitive Damages in Alabama: A Proposal for Reform, 26 Cumberland L. Rev. 1005 (1995-1996).

${ }^{99}$ Michael C. DeBow, The Road Back from "Tort Hell”: The Alabama Supreme Court, 1994-2004, at 3 (The Federalist Soc'y for Law \& Pub. Policy Studies, Oct. 15, 2004), available at http://www.fed-soc.org/doclib/ 20070325_alabama2004.pdf, accessed 7/5/2009).

${ }^{100} \mathrm{Id}$.

${ }^{101}$ George L. Priest, Punitive Damages Reform: The Case of Alabama, 56 Louisiana L. Rev. 825, 827-28 (1996). The data were reported to have been collected "for the case Gallant v. Prudential." Id. at 828 n.16. The study did not report the rate at which plaintiffs were granted punitive damages. 
struck down as violating the state constitutional right to jury trial was a $\$ 250,000$ cap on punitive damages. ${ }^{102}$ In BMW of North America, Inc. v. Gore, the U.S. Supreme Court reversed an Alabama Supreme Court decision and held that a 500-to-1 ratio of punitive to compensatory damages violated federal due process rights. ${ }^{103}$

Whatever the past reality of punitive damages in Alabama, the state has substantially changed. By 2004, a critic of Alabama punitive damages law noted that: "It would be difficult to find a state supreme court that has changed more in the last decade than the Alabama Supreme Court." 104 After reviewing several cases, he concluded: "Pretty clearly, Alabama punitive damages practice has changed a great deal since the days of BMW . Gore." 105 In 2007, it was noted that Alabama had not been included on the American Tort Reform Foundation's list of judicial hellholes for four years. ${ }^{106}$

How did the Chamber's respondents reflect the pro-business changes in Alabama punitive damages law? They penalized Alabama in the rankings. In 2002, respondents ranked Alabama third from last with respect to punitive damages; in 2008, despite substantial change, respondents ranked Alabama second from last. ${ }^{107}$ Consistently with the respondents' failure to adjust to legal changes in Louisiana, Mississippi, Texas, and West Virginia, the Alabama respondents seem unaware of changes in punitive damages or unable to update their views. Respondents' inflexibility is consistent with evidence from other states that respondents know little about the states they rank.

\section{Respondents' Denominator Problem: Biasing Results Against Large States}

Some states ranked low by the Chamber are not Gulf Coast states and were not early supporters of tobacco litigation. These tend to be large states such as California, Illinois, and Pennsylvania. The respondents' hostility to large states may be an instance of what can be called the "denominator problem." People have trouble making rational decisions when the decisions require properly accounting for the denominator in assessing the likelihood of events. They tend to focus on the number of events rather than on the rate of events.

The results of one leading experiment along these lines read in part as follows:

When offered an opportunity to win $\$ 1$ on every "win" trial in which they drew a red jelly bean, subjects frequently elected to draw from a bowl that contained a greater absolute number, but a smaller proportion, of red beans (e.g., 7 in 100) than from a bowl with fewer red beans but better

\footnotetext{
${ }^{102}$ Henderson v. Alabama Power Co., 627 So. 2d 878 (Ala. 1993).

${ }^{103}$ BMW of N. Am., Inc. v. Gore, 517 U.S. 559 (1996).

${ }^{104}$ DeBow, supra note 99 , at 1.

${ }^{105}$ Id. at 5 (footnote omitted).
}

${ }^{106}$ R. Harrison Smith, Commentary, A Key Time for Qui Tam: The False Claims Act and Alabama, 58 Ala. L. Rev. 1199, $1212(2007)$.

1072002 Survey at $21 ; 2008$ Survey at 18. 
Figure 4: Chamber grade and state population, 2008.

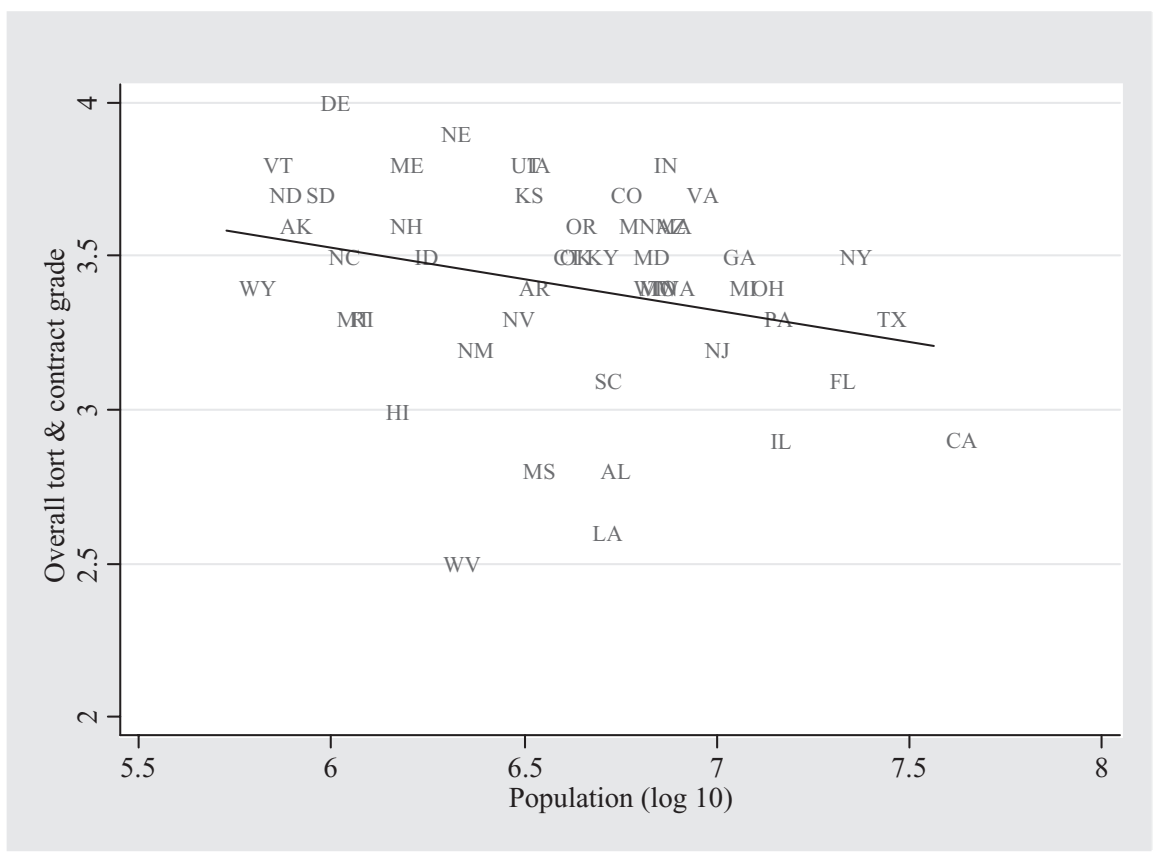

Note: Figure shows the relation between each state's 2008 survey overall tort and contract grade and state population.

SOURCE: 2008 Survey.

odds (e.g., 1 in 10). Subjects reported that although they knew the probabilities were against them, they felt they had a better chance when there were more red beans. ${ }^{108}$

The larger number of red beans, more events, distracted subjects from the true rates.

This information processing problem may explain why the Chamber's respondents disfavor legal environments in populous states. Populous, low-ranked states' legal systems may act against the Chamber's members' interest at a lower rate than more highly ranked states. But the Chambers' respondents' difficulty in accounting for the larger number of cases in large states may prevent the respondents from ranking rationally.

Figure 4 shows the relation between the 2008 Chamber grade for overall contract and tort litigation and state population. The figure shows a negative correlation, with a correlation coefficient of -0.28 and a significance level of 0.049 . If one excludes four obvious outliers in the figure (Alabama, Louisiana, Mississippi, and West Virginia), the correlation coefficient is a reasonably strong $(-0.42)$ and the significance level is 0.004 . The figure's straight line is 
the linear regression line, which clearly slopes downward. The outliers are either Gulf Coast states, prominent tobacco/asbestos litigation states, or both. So adverse outcomes may affect Chamber members in populous states, leading to low rankings. But more outcomes of all kinds occur in populous states and the respondents may not account for this in evaluating states. ${ }^{109}$

\section{A Single Factor State-Specific Explanation}

Further analysis of New Jersey suggests that a state's grade can plummet for all elements based on one or two events, and events of all kinds are more likely to occur in populous states because any particular legal event tends to be more likely to occur in a populous state. New Jersey's questionable class action decline analyzed in Section IV likely related more to non-class-action events than to class action developments. The Chamber's comment on New Jersey's combined-grade decline to 35th place in 2008, from 26th place in 2007, is revealing. Chamber CEO Tom Donohue attributed the decline to "the plaintiff-friendly bias in a handful of trial courts, particularly in lawsuits aimed at pharmaceutical manufacturers." 110 New Jersey's 2008 decline in rank likely stemmed largely from a 2007 multi-million dollar verdict, which included punitive damages, in the New Jersey state court Vioxx trial in the case of Humeston v. Merck E Co., Inc. ${ }^{111}$ New Jersey's Atlantic County's initial appearance on a judicial hellhole list has been largely attributed to Vioxx litigation. ${ }^{112}$

Did Merck's trial loss support Mr. Donohue's claim of "plaintiff-friendly bias"? In addition to other evidence, ${ }^{113}$ Merck-funded researchers reportedly withheld reports of Vioxx-user heart attacks from an article submitted to the New England Journal of Medicine $(N E J M)$. NEJM editors published an "Expression of Concern" about the researchers'

\footnotetext{
${ }^{109}$ Comparing states across a demographic element such as population usually cannot be conclusive evidence that the demographic element causes the measure being compared. This is because demographic elements such as population, race, income, and urban concentration tend to be correlated.
}

${ }^{110}$ ILR, http://www.instituteforlegalreform.com/component/ilr_states/18/state/NJ.html, accessed 6/20/ 2009. Merck lost a New Jersey state court trial relating to Vioxx in April 2006, before the 2008 Survey period. Wyeth lost a New Jersey state court trial relating to Fen Phen in October 2008, after the 2008 Survey was completed. See Ed Silverman, Wyeth Loses Diet Pill Lawsuit Over Lung Ailment, http://www.pharmalot.com/2008/10/wyeth-loses-diet-pill-lawsuitover-lung-ailment/, accessed 6/29/2009. In 1997, under pressure from the FDA, American Home Products Corp. (later Wyeth) withdrew from the market its diet drugs Pondimin (fenfluramine) and Redux (dexfenfluramine). Fen Phen, a combination of Pondimin and a mild stimulant called phentermine, was widely prescribed for weight loss. The pressure to withdraw came after Mayo Clinic research showed 24 cases of rare heart valve disease in women who took Fen Phen. See generally In re Diet Drugs (Phentermine, Fenfluramine, Dexfenfluramine) Prods. Liab. Litig., 553 F. Supp. 2d 442, 449 (E.D. Pa. 2008).

\footnotetext{
${ }^{111}$ Frederick \& Mary Humeston v. Merck \& Co., No. ATL-L-2272-03, 3/12/2007. The jury verdict forms in Humeston are available at http://www.judiciary.state.nj.us/mass-tort/vioxx/index.htm, accessed 6/30/2009.

${ }^{112} \mathrm{ATRF}$, supra note 51 , at $16-17$.

${ }^{113}$ For a review of scientific evidence in Vioxx trials, see McDarby v. Merck \& Co., 949 A.2d 223 (N.J. Super. 2008), certification granted in part $\mathcal{E}$ denied in part, 960 A.2d 393 (2008).
} 
behavior. ${ }^{114}$ After Merck responded, the NEJM editors reaffirmed their concern and stated that the article "did not contain relevant safety data available to the authors more than four months before publication, did not accurately reflect the potential for serious cardiovascular toxicity with rofecoxib [Vioxx]." 115 So safety information about Vioxx was withheld, a plaintiff who had suffered an adverse cardiovascular event sued and prevailed in a trial conducted in New Jersey. Prior to 2007, New Jersey juries had ruled for Merck in a previous Humeston trial, in Doherty $v$. Merck (2006) ${ }^{116}$ and against a plaintiff whose case was tried jointly with Humeston's. ${ }^{117}$ A jury split in the New Jersey Cona and McDarby Vioxx cases in 2006. ${ }^{118}$ The scientific evidence and pattern of verdicts does not establish bias and Mr. Donohue provided no information supporting his claim.

Whether or not New Jersey's overall rank should have declined based on the Humeston case, New Jersey's larger decline in class actions and other survey elements is evidence that a single-factor can drive the Chamber's respondents. The loss of a major drug trial likely gave respondents a negative impression of events in New Jersey. This translated into reduced grades for New Jersey in class action and venue elements, not based on what happened with respect to these elements, but because a negative impression translated into a lower grade for all elements.

In fact, New Jersey's rank declined in every element from 2007 to 2008. Thus, in a single year, according to respondents, New Jersey judges became less competent and impartial, its discovery system deteriorated, its ability to process motions for dismissal and summary judgment worsened, its juries became less fair and predictable, and its courts' ability to evaluate scientific and technical evidence declined. The implausibility of New Jersey's results confirms Figure 2's message that a single factor can drive a state's ranking. Respondents likely ranked New Jersey on all survey elements based on one factor, the adverse outcome of publicized drug litigation.

The only element in which New Jersey did not decline in 2008 was punitive damages and that too is revealing. No decline occurred because, as noted above, through 2007 the Chamber incorrectly denied that New Jersey allowed punitive damages and failed to report grades for that element. The Humeston punitive damages award apparently informed the Chamber's respondents of what was widely known-that New Jersey allows punitive

\footnotetext{
${ }^{114}$ Gregory D. Curfman, Stephen Morrissey \& Jeffrey M Drazen, Expression of Concern: Bombardier et al., "Comparison of Upper Gastrointestinal Toxicity of Rofecoxib and Naproxen in Patients with Rheumatoid Arthritis," New Eng. J. Med. 2000;343:1520-8, 353 New Eng. J. Med. 2813 (Dec. 29, 2005).

${ }^{115}$ Gregory D. Curfman, Stephen Morrissey \& Jeffrey M Drazen, Expression of Concern Reaffirmed, 354 New Eng. J. Med. 1193 (Mar. 16, 2006).

${ }^{116}$ Elaine \& Daniel Doherty v. Merck \& Co., No. ATL-L-638-05-MT. The jury verdict form in Doherty is available at http://www.judiciary.state.nj.us/mass-tort/vioxx/index.htm, accessed 6/30/2009. ${ }^{117}$ Estate of Brian Hermans v. Merck \& Co., No. ATL-L-5520-05. The jury verdict form in Hermans is available at
http://www.judiciary.state.nj.us/mass-tort/vioxx/index.htm, accessed 6/30/2009.
}

${ }^{118}$ See McDarby v. Merck \& Co., 949 A.2d 223 (N.J. Super. 2008), certification granted in part $\mathcal{F}$ denied in part, 960 A.2d 393 (2008). 
damages. Only in 2008, when punitive damages in the visible Humeston case made the Chamber's position untenable, did it report respondents' New Jersey punitive damages grades.

\section{Other Methodological Problems}

The Chamber's survey does not account for the sample design or for industry, a widely recognized factor in studies of businesses. The failure to account for the sample design manifests itself in at least three ways.

\section{A. Failure to Account for Disproportionate Sampling}

The Chamber acknowledged that its sampling technique could lead to oversampling of some industries. The 2002 survey reported that insurance companies were substantially oversampled. Insurance companies were overrepresented by 73.3 percent in the 2002 sample, ${ }^{119}$ and the degree of under- or overrepresentation of other industries in 2002 and other years is not known. It is standard statistical practice to account for survey over- or undersampling through the use of probability weights. The use of such weights accounts for the fact that oversampled subgroups are representing fewer unobserved members of a subgroup population than are undersampled groups. The standard statistical adjustment is to weight observations by the inverse of the probability of an observation being in the sample. ${ }^{120}$ The Chamber acknowledged that it had oversampled but no indication exists that the Chamber performed the necessary adjustment. When combining elements across states or making comparisons over time, as the Chamber has done, ${ }^{121}$ or across states (the central purpose of the survey) the Chamber's methodology precludes obtaining reliable results. ${ }^{122}$

The incorrect results that failing to account for over- or undersampling can lead to can be simply illustrated. Assume one wants to survey a random sample of citizens about approval ratings for police but is concerned that a pure random sample would produce too few members of a minority group. One therefore designs the sample to assure large enough representation of that group. Suppose the minority group accounts for 10 percent of the population and 50 percent of the sample. And suppose the minority group's views differ from the 90 percent majority so that 25 percent of the minority population approves of the police

\footnotetext{
${ }^{119} 2002$ Survey at 6 .

${ }^{120}$ E.g., Earl Babbie, The Practice of Social Research 213-15 (11th ed. 2007).

${ }^{121}$ E.g., 2008 Survey at 7.
}

${ }^{122}$ In recent years, the Chamber appears to strive for proportionate representation of insurance companies in its sample. 2008 Survey at 28. This suggests that the Chamber's analysis may need to account for the stratification of the sample into insurance company and other company components. No other industry receives the treatment of insurance companies. Knowing the extent to which results depend on insurance company responses is especially important for states, such as Louisiana, that allow direct actions against insurers. La. Rev. Stats. 22:655. Insurance companies may have greater hostility toward and/or familiarity with direct action states. 
compared to 75 percent of the majority group. Simply averaging the responses to arrive at an aggregate figure would yield a 50 percent approval rating. But that would be an incorrect aggregate figure. Minority group members had a much larger probability of being in the sample than did majority group members. They were nine times more likely to be sampled than majority group members, and that oversampling must be accounted for. The correct aggregate figure is 70 percent police approval, not 50 percent. This illustrates how badly off the Chamber's reports of some items may be, even as a representation of the views of an already biased sample.

\section{B. Failure to Account for Multiple Observations by a Subject}

As described in Section II, the Chamber allows a respondent to evaluate 10 states in recent years. The respondent need only report some familiarity with multiple states' legal systems. Observations by the same respondent obviously are not independent of one another. Proper statistical practice requires accounting for this nonindependence in assessing statistical significance. ${ }^{123}$ The Chamber does not, and the methodological appendix the Chamber supplies about statistical significance does not, address this issue. ${ }^{124}$ So a single responding counsel may declare himself or herself familiar with 10 states, give them all low, high, or varying rankings, and the consumer of the survey does not know whether that single counsel influenced multiple states' rankings. The consumer only knows that the Chamber did not account for nonindependence.

The issue is of potentially substantial magnitude. For example, the 2008 survey reports that 957 responses were received. ${ }^{125}$ That is about only 19 responses per state. Even a nonpopulous state such as Alaska had 40 responses. ${ }^{126}$ So every state's ranking depends heavily on the same subjects ranking multiple states. Corporate counsel for a New Jersey drug company unhappy with a loss at trial can rank New Jersey low and rank nine other states high. The Chamber's analysis does not account for this nonindependence.

\section{Failure to Account for Varying Familiarity with a State}

As described in Section II, the Chamber allows responses from subjects who self-report that they are "very or somewhat familiar with that state." The less-than-10 percent accuracy of

\footnotetext{
${ }^{123}$ E.g., Charles R. Shipan, Partisanship, Ideology, and Senate Voting on Supreme Court Nominees, 5 J. Empirical Legal Stud. 55 (2008).

${ }^{124}$ E.g., 2008 Survey at 30-32. The appendix does note that the figures it supplies for assessing statistical significance are based on comparing "independent" groups. Id. at 32. So the Chamber apparently knows that the appendix does not supply information sufficient to assess the statistical significance of its results, which do not contain fully independent groups. In recent years, the appendix also supplies insufficient information to assess the sampling error of any response for any state. The appendix table labeled "Recommended Allowance for Sampling Error of Proportions" provides information for sample sizes of 400 or greater. Id. at 31. Since the number of respondents for no state even approaches 400 , one cannot use the appendix to assess the sampling error for responses about any state.
}

\footnotetext{
${ }^{125}$ Id. at 28 .
}

${ }^{126}$ Id. at 39 
objectively verifiable responses casts doubt on the respondents' candor or ability to assess their own knowledge. Given the importance of familiarity with a state, a better practice would call for the Chamber to report results separately for those claiming that they are "very" familiar with a state and those claiming that they are "somewhat" familiar with a state. The Chamber could still aggregate the two categories of respondents if it wished, but the survey's consumers and states being ranked are entitled to know the extent to which rankings stem from respondents less familiar with a state.

\section{Failure to Account for Industry}

The Chamber's failure to account for insurance industry oversampling in 2002, noted above, relates to another problem. Motor vehicle manufacturers, insurance companies, pharmaceutical companies, and other industries have different characteristics that scholars usually recognize as requiring accounting for industry in empirical work. Studies of businesses regularly recognize the importance of accounting for industry effects. ${ }^{127}$ The Chamber fails to do so, and that failure has important implications for those the Chamber wishes to influence with the survey. For example, as noted above, the Chamber reported that New Jersey plummeted in rank due to "local bias" in drug cases. ${ }^{128}$ One cannot tell whether this is due to the disgruntlement of a drug company's counsel who lost at trial, or to a more general perception about New Jersey across industries. Policymakers whom the Chamber seeks to influence deserve to know whether a state's rank results from a company's counsel being embarrassed by a loss at trial. ${ }^{129}$

\section{Conclusion}

It is surprising how little Chamber respondents know and how unresponsive they are to changes in their legal environment. This raises a question about the quality of the lawyers who respond to the survey. The survey methodology may generate a kind of lemon effect. Poorly informed, inflexible lawyers may be associated with companies' decisions to press to trial and trial losses. These weak lawyers are the ones most likely to be upset and to respond

\footnotetext{
${ }^{127}$ E.g., Michael G. Hertzel \& Janet Kiholm Smith, Industry Effects of Interfirm Lawsuits: Evidence from Pennzoil v. Texaco, 9 J. Law, Econ. \& Org. 425 (1993); Anita M. McGahan \& Michael E. Porter, How Much Does Industry Matter, Really?, 18 Strategic Mgmt. J. 15 (1997) ("industry structure is a central determinant of firm performance, and firm differences are considered against an industry background").
}

${ }^{128}$ ILR, http://www.instituteforlegalreform.com/component/ilr_states/18/state/NJ.html, accessed 6/20/2009.

${ }^{129}$ Bias against drug companies in New Jersey is somewhat implausible. Several large drug companies, including Merck, Bristol-Myers Squibb, Johnson \& Johnson, and Wyeth (acquired by Pfizer), are headquartered in New Jersey. For summary information about the drug industry's presence in New Jersey, see http://www.locationnj.com/ NJ_Pharmaceuticals_Profile.asp, accessed 7/28/2009. A large Swiss drug company, Octapharma, moved its U.S. headquarters from Virginia, a state favored by Chamber respondents, to New Jersey after the Humeston trial. PR Newswire, Octapharma to Move $\mathrm{HQ}$ to Hoboken, NJ, http://www.securityinfowatch.com/ContractWatch/ octapharma-move-hq-hoboken-nj, accessed 7/1/2009. 
to the survey. They provide a biased picture of liability systems that is out of touch with reality.

The consistently low ranking of many states despite changes in their legal environments may also suggest a political economy explanation. The Chamber needs devils to justify its tort reform budget. If it does not label at least some states as in desperate need of Chamber reform efforts, it might be less able to raise money from members. The Chamber thus needs liability villains and its survey annually assures that they are perceived to exist. The survey provides a respectable-looking social science gloss to statistically unsophisticated policymakers and media outlets.

The Chamber's willingness to villify states and counties to promote both itself and legislation may be the product of the same mentality that has led to shocking business failures. Companies, such as General Motors, with once seemingly impregnable market positions, spent excess time and effort lobbying for and against laws rather than seeking to improve their products. "If Detroit had spent less time lobbying for government protection and more on improving its products it might have fared better." ${ }^{130}$ The Chamber may be leading other members down a similar path. A credible argument exists that the Chamber harms business by irrationally discouraging investment. Based on the views of risk managers and those who seriously study the effect of the tort system, the Chamber may also unnecessarily endanger the public safety by decreasing tort law's deterrent effect.

The attention the survey receives illustrates the critical need for better, reliable, systematic information about the legal system. Absent such information, the informational vacuum will be filled by questionable special-interest data such as the Chamber's. ${ }^{131}$ In this respect, the survey has had a positive effect. It has prompted at least one state, West Virginia, to start a data-gathering program to assure accurate information about legal outcomes. ${ }^{132}$ It can then assess part of its judicial system's performance based on actual events. Other states should follow West Virginia's data initiative to assure widespread objective knowledge about how states' legal systems function.

The information must not only be gathered, but readily available for dissemination. Surveys on important issues that are as flawed as the Chamber's usually have muted impact because the other side to an issue responds with its own surveys. Democrats and Republicans often generate dueling polls and media campaigns on issues of public importance and likely undermine each others' most unsupportable claims. But the Chamber attacks an institution that is not accustomed to defending itself. State judiciaries lack the resources to respond to the Chamber's media campaigns and professional norms prevent the judiciaries from fully responding even if they could. Members of the bar and the social science community should act to generate and disseminate information needed to present an objective picture of court performance.

\footnotetext{
${ }^{130}$ The Economist, June 6, 2009, at 9.

${ }^{131}$ Theodore Eisenberg, Use It or Pretenders Will Abuse It: The Importance of Archival Legal Information, 75 UMKC L. Rev. 1 (2006).
} 